\title{
14. LATE MIOCENE TO RECENT PLANKTONIC FORAMINIFERS FROM THE NORTH ATLANTIC: DEEP SEA DRILLING PROJECT LEG 941
}

\author{
P. P. E. Weaver, Institute of Oceanographic Sciences, Wormley, Surrey ${ }^{2}$
}

\begin{abstract}
The main objective of DSDP Leg 94 was to study North Atlantic late Neogene environments. The six drill sites underlie a range of present-day environments from subtropical to subpolar, and all except one are characterized by high sedimentation rates and minimal reworking.

Coring by Hydraulic Piston Corer, Advanced Piston Corer, and Extended Core Barrel ensured a complete record back to at least $2.4 \mathrm{Ma}$ at all sites, but core recovery beyond this level was also excellent. Good core recovery and minimal reworking combined to give excellent sections for biostratigraphy. The quality of the results is also enhanced by an excellent paleomagnetic stratigraphy. The distribution of sites has made it possible to determine north-south variations in stratigraphic distributions of species.

At Sites 606 and 607, the subtropical stratigraphic zonation of Berggren (1973) can be applied. At Site 608 some of the species employed in this zonation are rare or absent, and at Sites 609,610 , and 611 the zonation is inadequate. Previous high-latitude zonations have suffered from poor core recovery and a lack of paleomagnetic control, so that stratigraphic ranges were not always accurately quoted. An informal high-latitude stratigraphy which may be of more value is outlined at the end of this chapter.
\end{abstract}

\section{INTRODUCTION}

During DSDP Leg 9421 holes were drilled at six sites in the North Atlantic (Fig. 1, Table 1). The primary objective of this cruise was to study late Neogene environments in the North Atlantic, so that the results could be compared with those of previous paleoenvironmental DSDP cruises in the central equatorial Pacific (Leg 85) and northwest and southwest Pacific (Legs 86 and 90, respectively). The sites chosen to fulfill such objectives necessarily had high deposition rates with minimum erosion or hiatuses, criteria also essential in gaining good stratigraphic resolution. The north-south transect has allowed zonation schemes to be tested over a wide latitudinal area.

The southernmost Site 606 anchors the transect in the northern part of the modern subtropical gyre. Site 607 also lies at the northernmost end of the subtropical gyre, but received a greater impact of Quaternary glaciations. Site 608 lies just south of the maximum penetration of polar water during glacial periods and in the intermediate zone during interglacials, whereas Site 609 was overlain by polar water during severe glacials and lies at the southern margin of the subpolar gyre at the present day. Sites 610 and 611 both lie under the present-day subpolar gyre, and were under polar water during glacial maxima.

Deposition rates at Sites 606, 607, and 609 were considerably above the carbonate production rate of about 20 m/m.y. for mid-gyre North Atlantic regions. Deposition rates reached $72 \mathrm{~m} / \mathrm{m}$.y. at Site 609 and averaged 40 and $44 \mathrm{~m} / \mathrm{m}$.y., respectively, at Sites 606 and 607 . None of these sites shows significant evidence of reworking,

\footnotetext{
${ }^{1}$ Ruddiman, W. F., Kidd, R. B., Thomas, E., et al., Init. Repts. DSDP, 94: Washington (U.S. Govt. Printing Office). rey, GU8 SUB, U. K.
}

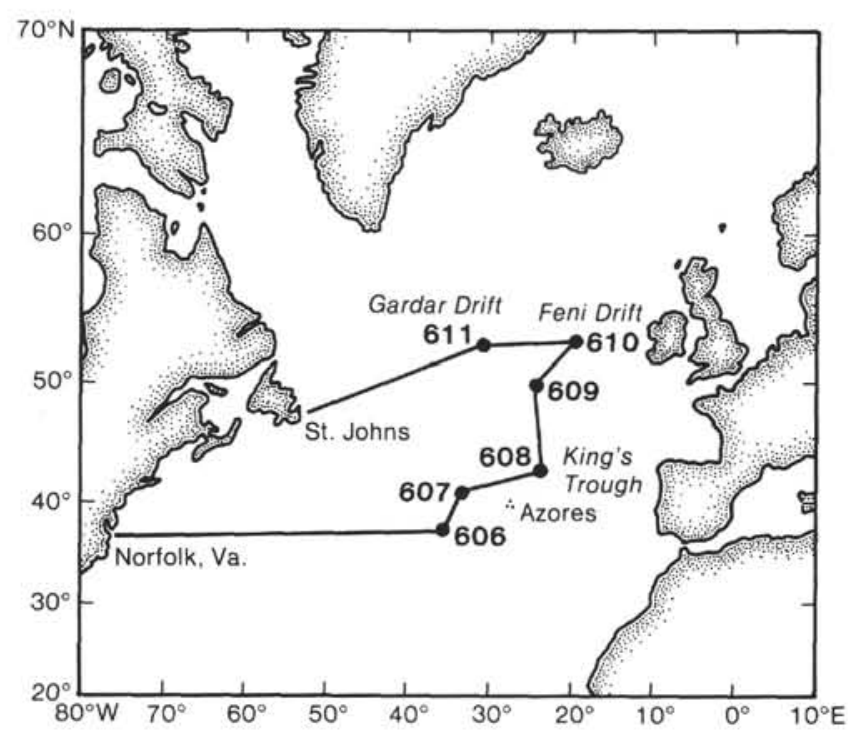

Figure 1. Locations of Leg 94 sites.

however; it is assumed that increased current activity around local basement outcrops caused these outcrops to remain sediment-free, the sediment being deposited instead on the adjacent flatter areas. Sites 610 and 611 are on Feni and Gardar sediment drifts, respectively. Both had sedimentation rates in excess of $50 \mathrm{~m} / \mathrm{m} . \mathrm{y}$. through the late Miocene to Recent, but again the redistribution of sediment seems to have been contemporaneous with normal deposition. Very little reworking was found, except in some of the glacial sediments, with material derived from ice-rafting. The high deposition rates and good preservation allow high stratigraphic resolution, generally without problems caused by reworking.

The site locations are generally in relatively shallow areas (Table 1); the deepest site, 609 , is at $3871 \mathrm{~m}$ water 
Table 1. Site locations and water depths, Leg 94.

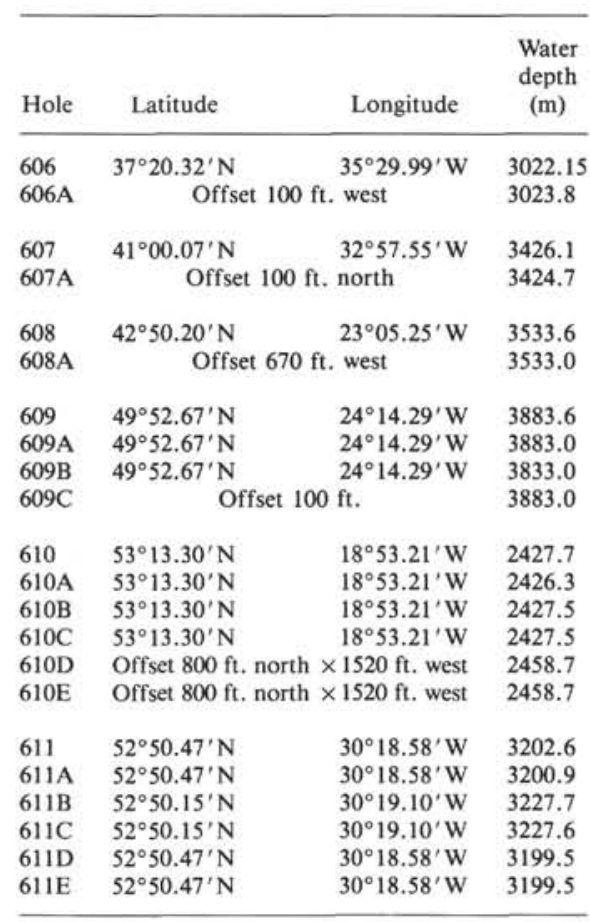

depth. Dissolution is therefore not a problem in the Quaternary and Pliocene sediments, but a shallower calcium carbonate compensation depth (CCD) during the late Miocene has caused varying amounts of dissolution in sediments of this age. Paleoenvironmental reconstructions and age determinations become increasingly difficult when part of the fauna has been removed by dissolution, particularly when the most robust faunal elements are cooler-water species such as Neogloboquadrina spp.

The main objective of the cruise was to obtain a complete stratigraphic section dating back to at least $2.4 \mathrm{Ma}$ at all sites. This was achieved by double Hydraulic Piston Corer (HPC)/Extended Core Barrel (XCB) coring at all sites (except 606, which was cored with the Advanced Piston Corer [APC]) and covering gaps still present by successive third and fourth holes (Ruddiman et al., this volume). At the sediment drift sites, attempts were made to core in both sediment wave-crests and -troughs.

\section{MATERIALS AND METHODS}

Samples were prepared simply by drying and then soaking in water. This was found to be sufficient to give complete breakdown in most cases, although in a few of the older samples it was necessary to repeat the process. All samples were washed through a $63-\mu \mathrm{m}$ sieve, but the analyses were carried out on the $>150-\mu \mathrm{m}$ fraction.

\section{SITE SUMMARIES}

\section{Site 606 (Tables 2 and 3)}

Two holes were drilled at this site, both terminating in the lower Pliocene. No major differences were found between the holes, and they can be treated as a single section.

The site lies in the northern part of the present-day subtropical gyre at a water depth of $3007 \mathrm{~m}$ (Table 1;
Fig. 1). All samples examined contain abundant and wellpreserved planktonic foraminifers. Species diversities are high throughout, with over 20 species present in most samples. Subtropical-transitional species such as Globorotalia inflata, G. truncatulinoides and Globigerinoides ruber are common at this site, whereas tropical species such as Globigerinoides sacculifer, Pulleniatina obliquiloculata, and Sphaeroidinella dehiscens occur but are rare. Cooler-water species such as Neogloboquadrina pachyderma (dextrally coiled), Globigerina quinqueloba, and Globigerinita glutinata occur commonly throughout. Glacial intervals were revealed by subtle changes in the fauna rather than by wholesale replacements of faunal groups.

The southerly position of this site makes it possible to use the subtropical zonation of Berggren (1973; 1977; Fig. 2) for the Pliocene, with the G. truncatulinoides (N22) Zone of Blow (1969) representing the Quaternary.

The base of Zone N22 is taken to be at the first appearance of $G$. truncatulinoides (Blow, 1969). At this site, however, this is a first occurrence datum, not an evolutionary appearance, since Globorotalia tosaensis, the ancestor of $G$. truncatulinoides, is too rare to enable the full evolutionary sequence to be followed. Many of the early specimens of $G$. truncatulinoides at this site lack a keel on the early chambers, but the first $G$. truncatulinoides occur in Samples 606-5,CC and 606A-6,CC; other micropaleontologic and magnetic data place $606-6, \mathrm{CC}$ stratigraphically above 606A-6,CC, however, suggesting that the whole of Core 606-6 lies in Zone N22. No formal subdivision of this zone has been made, but pink Globigerinoides ruber occurs in 606-1,CC, 606-2,CC, and 606A-1,CC, suggesting a latest Quaternary age for these samples. Globorotalia hirsuta is present in 606$1, C \mathrm{C}$ and $606 \mathrm{~A}-1, \mathrm{CC}$, suggesting an age younger than oxygen-isotope stage 12, according to Pujol and Duprat (1985). Apart from these species, the Quaternary samples contain diverse assemblages in which Globorotalia inflata, Globigerina bulloides, N. pachyderma (d), and G. ruber are generally the most common species. G. truncatulinoides appears to be more common in the upper part of the Quaternary, whereas Globorotalia crassaformis is more common in the lower part. Neogloboquadrina eggeri is very common in a short interval around the Pliocene/Quaternary boundary in both holes. A similar stratigraphic range for this species was given by $\mathrm{Pu}$ jol and Duprat (1983), who used its last occurrence datum (LAD) to mark their Quaternary D/E subzonal boundary.

The uppermost Pliocene Globigerinoides obliquus extremus Zone (PL6) can be recognized between the extinction of Globorotalia miocenica and the first appearance of $G$. truncatulinoides. The nominate subspecies of this zone is, however, rare to absent, as it is in the South Atlantic (Pujol, 1983). Apart from the absence of G. truncatulinoides, the fauna of this zone is very similar to that in Zone N22. The base of Zone PL6 lies between Samples 606-9-3, 118-120 cm and 606-9-1, 118$120 \mathrm{~cm}(71.2-74.2 \mathrm{~m})$. In Hole 606A the base has not been determined, since the topmost sample with $G$. miocenica $(606 \mathrm{~A}-8, \mathrm{CC})$ also contains a large number of lower Pliocene reworked specimens (identified in Table 3 by 
Table 2. Distribution of planktonic foraminifers, Hole 606.

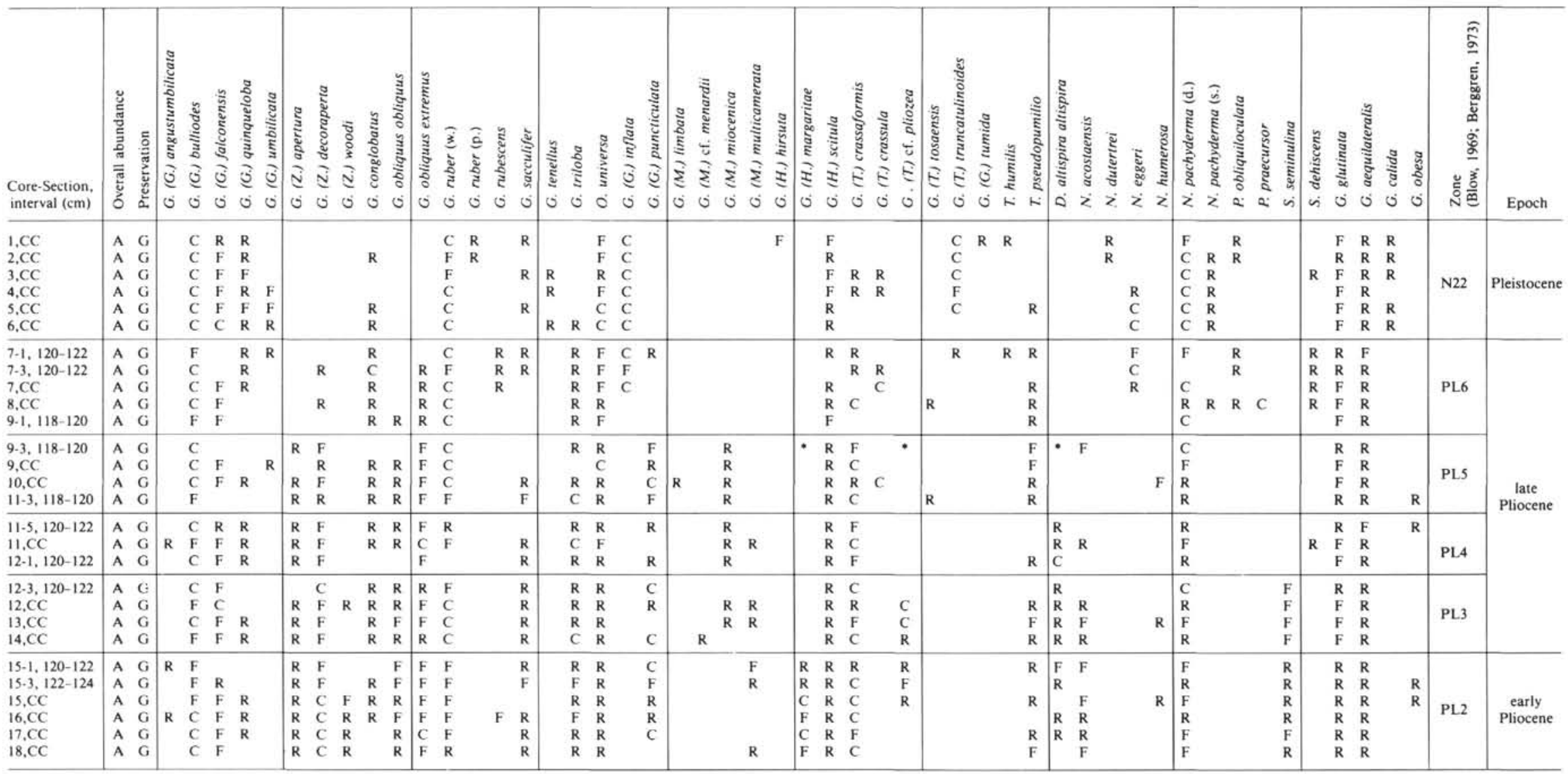

Note: Overall abundance: $\mathrm{A}=$ abundant. Preservation: $\mathrm{G}=$ good. Species abundance: $\mathrm{C}=$ common $(15-30 \%) ; \mathrm{F}=\mathrm{Few}(3-15 \%) ; \mathrm{R}=$ rare $(<3 \%) ; \boldsymbol{\theta}^{*}=$ reworked specimens. 
Table 3. Distribution of planktonic foraminifers, Hole 606A.

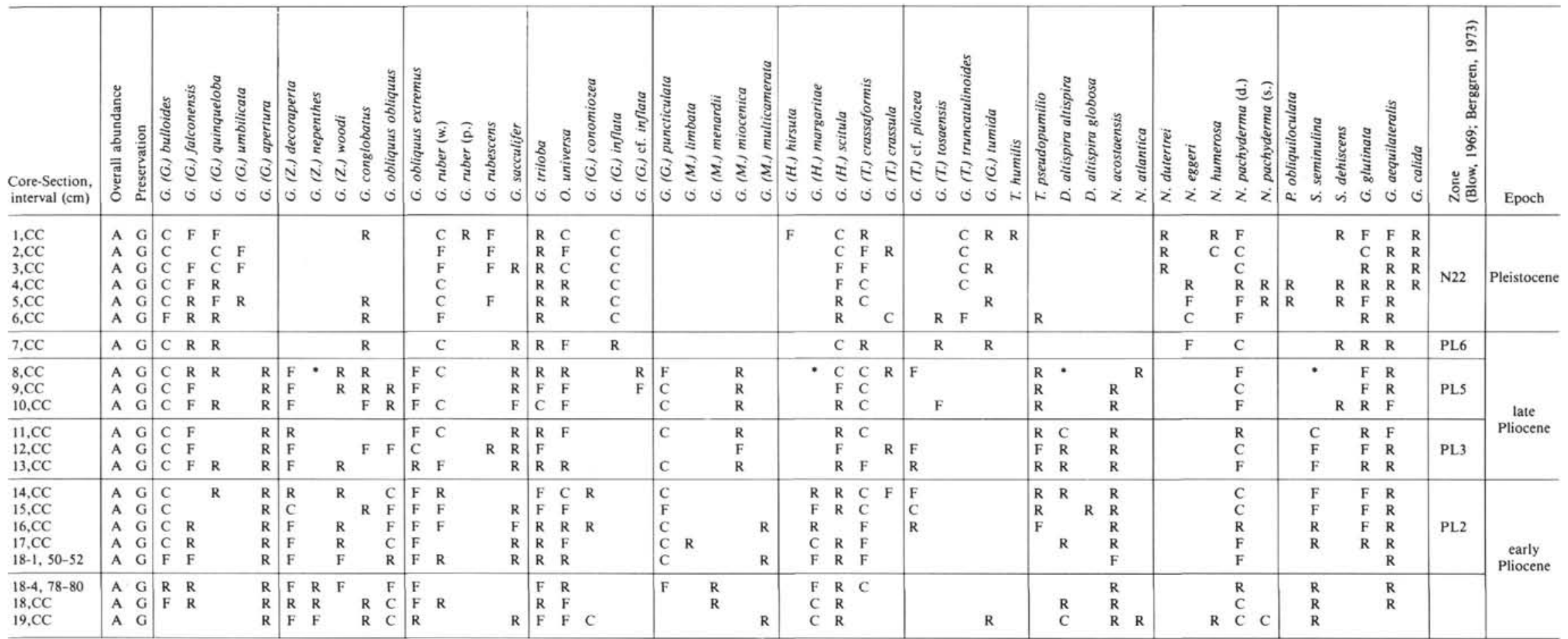

Note: Overall abundance: $\mathrm{A}=$ abundant. Preservation: $\mathrm{G}=\operatorname{good}$. Species abundance: $\mathrm{C}=$ common $(15-30 \%) ; \mathrm{F}=$ few $(3-15 \%) ; \mathrm{R}=\operatorname{rare}\left(\langle 3 \%) ;{ }^{*}=\right.$ reworked specimens. 


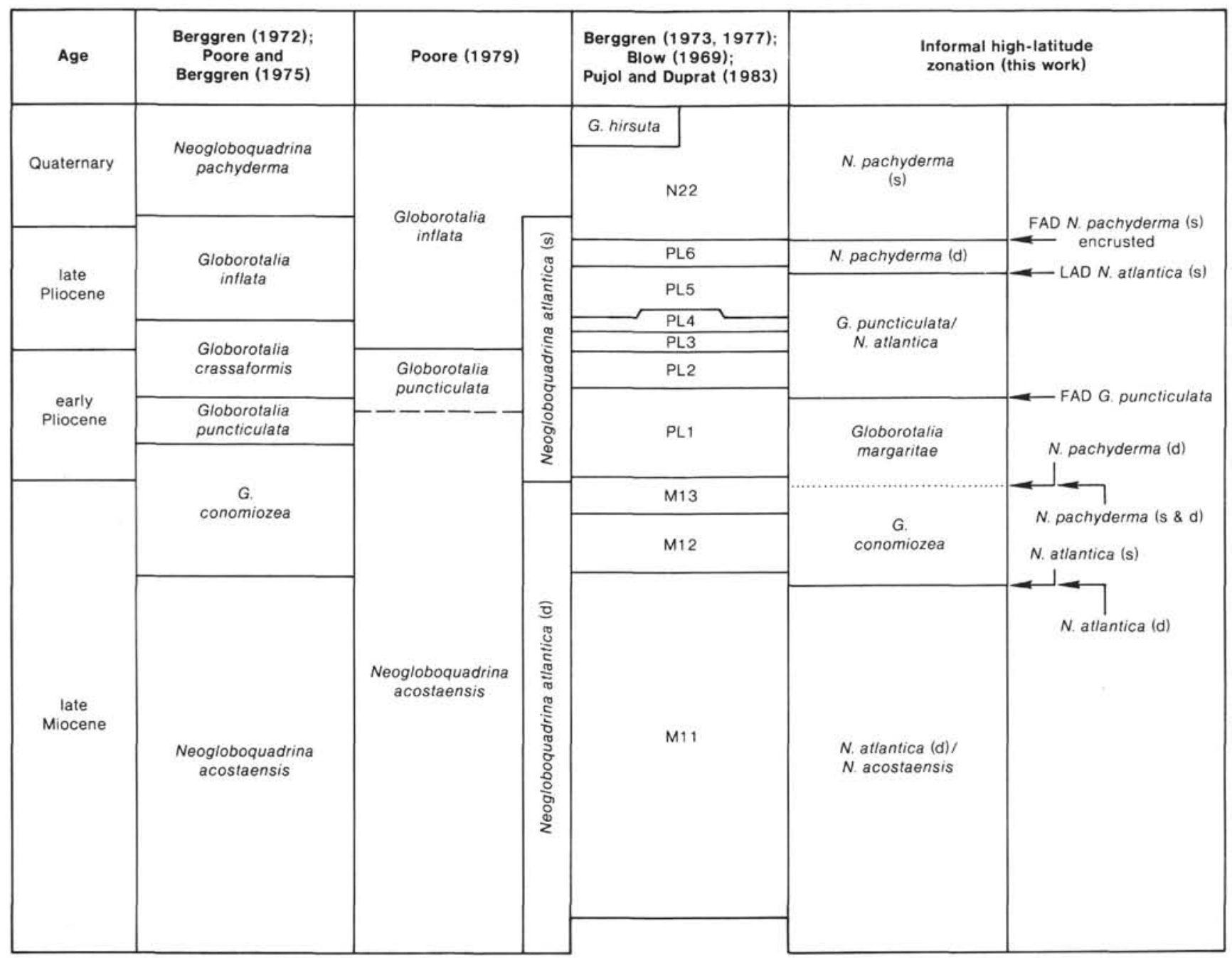

Figure 2. North Atlantic subtropical and high-latitude zonal schemes. Zonal schemes in second and third columns were not correlated with paleomagnetics and require revision. Zonal scheme in column 4 is very useful in subtropical regions. The most useful stratigraphic species in the high latitudes are depicted in columns 5 and 6.

asterisks), so that the true extinction point of this species cannot be identified in this hole.

The G. miocenica Zone (PL5) extends from the extinction of Dentoglobigerina altispira to the extinction of $G$. miocenica. Neither species is common at this site, but sufficient specimens of both can be found to identify the zone, which has its base in Core 606A-11 and between Samples 606-11-5, 118-120 cm and 606-11-3, $120-122 \mathrm{~cm}$ (93.5-96.4 m). The most common species in this zone are G. bulloides, G. ruber, G. crassaformis, and Globorotalia puncticulata. The top of this zone is marked by a decrease in $G$. puncticulata, which, together with its descendant species G. inflata, may be absent for a short interval around the PL5/PL6 boundary. Occasional specimens of $G$. puncticulata can, however, be found in Zone PL6, and a few specimens of $G$. inflata can be found below Zone PL6. Thus, there is an overlap of these two species. Specimens of Globigerina decoraperta and Globigerina apertura occur in Zone PL5, together with increased numbers of $G$. obliquus extremus. Neogloboquadrina pachyderma, conversely, is less com- mon, suggesting warmer water conditions than in Zones PL6 and N22.

The D. altispira Zone (PL4) extends from the extinction of Sphaeroidinellopsis seminulina to the extinction of $D$. altispira. It has its base between Samples 606-12-3, $120-122 \mathrm{~cm}$ and $606-12-1,120-122 \mathrm{~cm}(100-103 \mathrm{~m})$. This zone was not identified in Hole 606A, but it is a very short zone and may lie within Core 606A-11. The fauna of this zone is similar to that in Zone PL5, with the addition of rare $D$. altispira.

The $S$. seminulina Zone (PL3) extends from the extinction of Globorotalia margaritae to the extinction of S. seminulina. It has its base between Samples 606-15-1, $120-122 \mathrm{~cm}$ and 606-14,CC (127.2-128.6 m) and in Core 606A-14. S. seminulina is fairly common in this zone, and Globorotalia cf. crassula may also be common. The rest of the fauna is similar to that in the $D$. altispira Zone (PL4).

The base of the G. margaritae Zone (PL2) is marked by the extinction of Globigerina nepenthes. Hole 606 does not reach the base of this zone, but in Hole 606A the ex- 
tinction lies between Samples 606A-18-4, 78-80 cm and 606A-18-1, 50-52 cm (159.7-164.2 m). Globigerina decoraperta, G. bulloides, G. crassaformis, and G. margaritae are common throughout this zone.

The lowest two cores of Hole 606A penetrate the $G$. nepenthes Zone (PL1), which, apart from the addition of $G$. nepenthes, has a fauna similar to that of Zone PL2.

\section{Site 607 (Tables 4 and 5)}

Two holes were drilled at this site, giving a largely overlapping and partly composite section dating back to the late Miocene. No major differences were found between the holes, and they are treated as a single section.

The site lies less than $250 \mathrm{n}$. mi. north of Site 606 and has a fauna very similar to the one at that site. Preservation is good in the Quaternary and Pliocene but only moderate in the upper Miocene, where dissolution has reduced both the numbers of individuals and probably also the species diversity. The most common species at this site are G. bulloides, N. pachyderma (d), G. ruber, $G$. inflata, G. puncticulata and $G$. crassaformis. Subtropical species such as Globigerinoides sacculifer occur consistently but in small numbers, whereas the polar species N. pachyderma (sinistral) is generally rare even in glacial periods.

The subtropical zonation of Berggren (1973, 1977; Fig. 2) can be applied, even though some of the marker species are quite rare. The lowest occurrence of $G$. truncatulinoides is in Sample 607-9-1, 118-120 cm (74.4 m), which places the N22/PL6 boundary in Core 607-9. On the basis of paleomagnetic data, this boundary is placed in Core $607 \mathrm{~A}-9$, but $G$. truncatulinoides was not found in Sample 607A-8,CC. Globigerina bulloides, G. inflata, and N. pachyderma (d) are common throughout Zone N22, with the $G$. hirsuta Subzone of Pujol and Duprat (1985) recognizable in Cores 607-1 and -2 and Cores 607A-1 and -2 .

The base of the G. obliquus extremus Zone (PL6) lies between Samples $607-11, \mathrm{CC}$ and $607-11,5,118-120 \mathrm{~cm}$ (99.6-102 m) and in Core 607A-12, on the basis of the last occurrence of $G$. miocenica. The zonal species $G$. obliquus extremus is not consistently present, and is an unreliable marker. The fauna of this zone is similar to that of Zone N22; Neogloboquadrina eggeri spans the boundary.

The $G$. miocenica Zone (PL5) extends down to between Samples 607-14,CC and 607-14-5, 120-122 cm (128.4$130.8 \mathrm{~m}$ ) and to Core $607 \mathrm{~A}-15$, on the basis of the last occurrence of $D$. altispira. This zone contains $G$. puncticulata, $G$. decoraperta, and lesser numbers of $N$. pachyderma (d) than the zones above. The $D$. altispira Zone (PL4) contains a similar fauna, with the addition of very rare $D$. altispira. The base of the $D$. altispira Zone (PL4), marked by the extinction of $S$. seminulina, lies between Samples 607-15-3, 118-120 cm and 607-15-1, $118-120 \mathrm{~cm}(132-140 \mathrm{~m})$ and in Core 607A-16.

Zone PL3 extends to the extinction of $G$. margaritae, between Samples 607-18-5, 120-122 cm and 607-18-3, $120-122 \mathrm{~cm}(164.1-167.1 \mathrm{~m})$ and in Core 607A-19. It contains a fauna similar to that in Zone PL4, with the addition of numerous specimens of Globorotalia $\mathrm{cf}$. crassula. This species has only a short overlap with G. margaritae at the top of Zone PL2. Otherwise Zone PL2 contains common $G$. margaritae and an increased proportion of N. pachyderma (d). Globorotalia puncticulata and $G$. crassaformis are also common above their first occurrences near the base of this zone.

Zone PL1 is recognized by the overlap of $G$. margaritae with $G$. nepenthes. However, the base of this zone is defined by Berggren (1973) on the basis of the last occurrence of Globoquadrina dehiscens. This species does not occur in the samples examined from Site 607, and has elsewhere been shown to have a diachronic LAD (Kennett and Srinivasan, 1975). The lowest samples from both holes are, however, certainly older than the topmost Miocene extinction of $G$. dehiscens (Weaver and Clement, this volume), and must therefore belong to the late Miocene zones of Berggren et al. (1983). Owing to the absence of $G$. dehiscens, Zones PL1 and M13 cannot be distinguished. Further, the subdivision of Zone PL1, based on the successive first appearances of $G$. puncticulata and $G$. crassaformis, cannot be recognized, since both species first appear in Zone PL2 at this and other North Atlantic sites. Zones PL1 and M13 are therefore grouped together, and their base is defined by the first occurrence of $G$. margaritae. This lies between Samples $607-26-5,120-122 \mathrm{~cm}$ and 607-26-2, 120-122 cm (239.1$243.6 \mathrm{~m}$ ) and within the washed interval between Cores 607A-20 and 607A-21.

The samples below Zone PL1 have suffered varying degrees of dissolution, but a fauna can still be retrieved from all samples. Neogloboquadrina species are among the groups more resistant to dissolution (Berger, 1970), and they are very common in all these samples. It is very difficult to place Samples 607-26,CC to 607-30,CC and $607 \mathrm{~A}-21, \mathrm{CC}$ to $607 \mathrm{~A}-26, \mathrm{CC}$ into a zone, because of a lack of diagnostic species. The late Miocene zonal markers Globorotalia conomiozea and Globorotalia conoidea are absent at this site, but Globorotalia plesiotumida occurs sporadically throughout, indicating a late Miocene age.

\section{Site 608 (Tables 6 and 7)}

Two holes were drilled at this site, one to middle Eocene basaltic basement, the second into lower Pliocene sediments. This chapter is limited to upper Miocene to Recent sediments; the deeper samples in the longer Hole (608) are discussed by Jenkins (this volume). At this site some discrepancies occur between the depths of datums in the two holes. These suggest local sediment instability in the area, discussed later.

This site lies beneath an intermediate surface water mass during interglacials, but it lay just south of the polar front during glacial maxima (Weaver, 1983). Glacial/ interglacial differences in the planktonic foraminifers are well marked. Pliocene and Quaternary faunas are abundant and well preserved, whereas those in the upper Miocene are less common and only moderately well preserved. This reflects increased dissolution during the late Miocene. 
Table 4. Distribution of planktonic foraminifers, Hole 607.

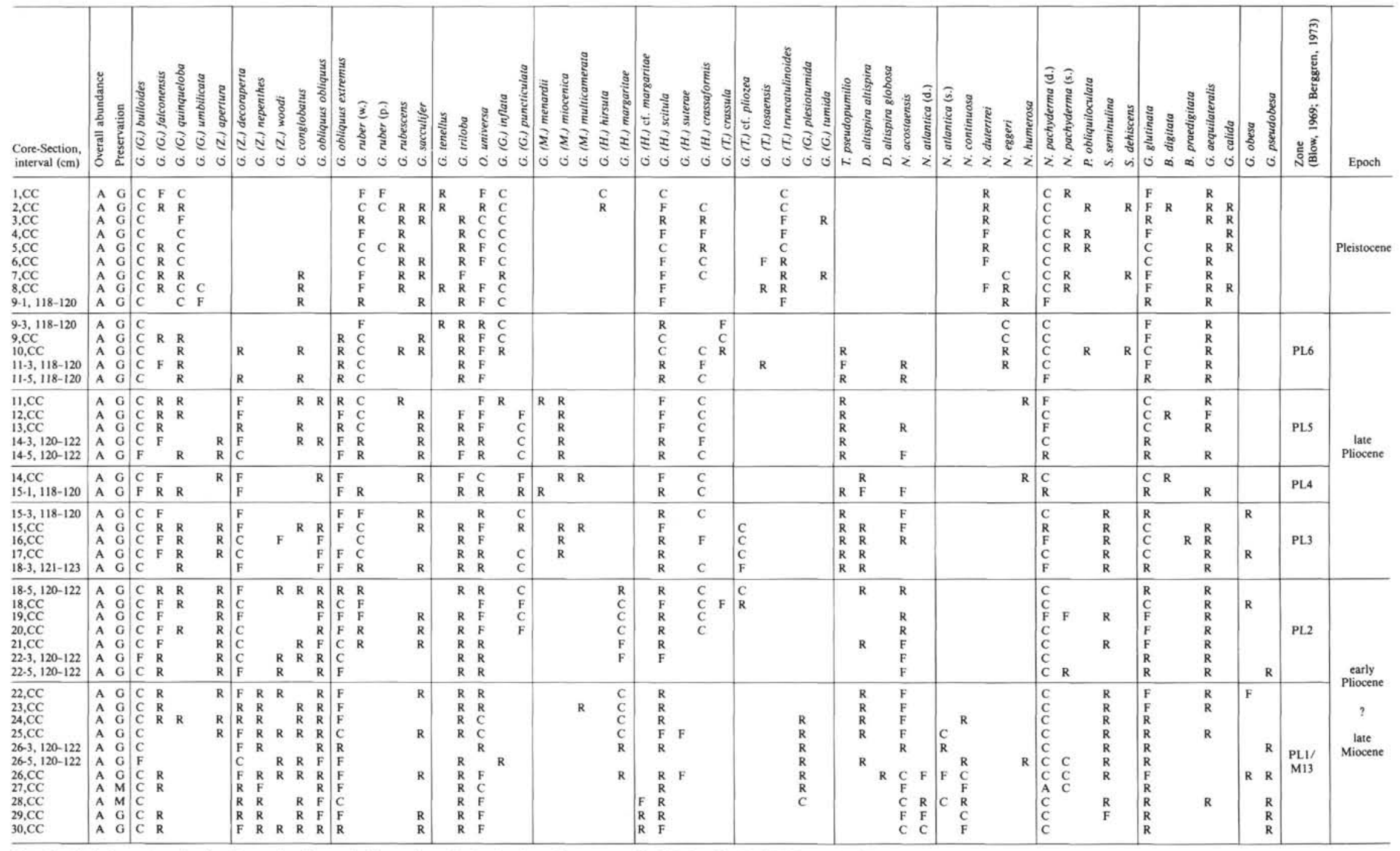

Note: Overall abundance: $\mathrm{A}=$ abundant. Preservation: $\mathrm{G}=$ good; $\mathrm{M}=$ moderate. Species abundance: $\mathrm{C}=\operatorname{common}(15-30 \%) ; \mathrm{F}=\mathrm{few}(3-15 \%) ; \mathbf{R}=$ rare $(\langle 3 \%)$ ). 
Table 5. Distribution of planktonic foraminifers, Hole 607A.

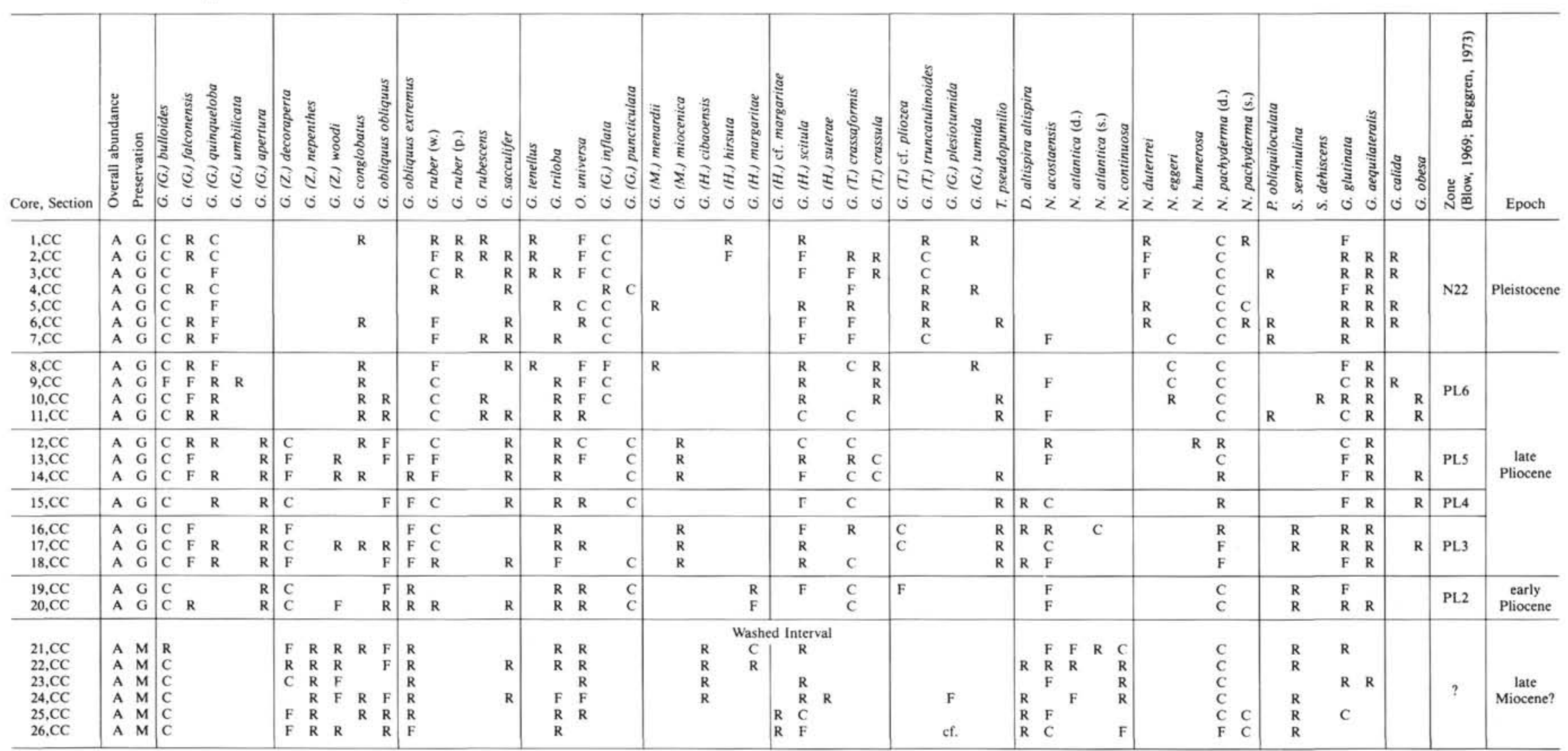

Note: Overall abundance: $\mathrm{A}=$ abundant. Preservation: $\mathrm{G}=$ good; $\mathrm{M}=$ moderate. Species abundance: $\mathrm{C}=$ common $(15-30 \%) ; \mathrm{F}=$ few $(3-15 \%) ; \mathrm{R}=$ rare $(<3 \%)$. 
Table 6. Distribution of planktonic foraminifers, Hole 608.

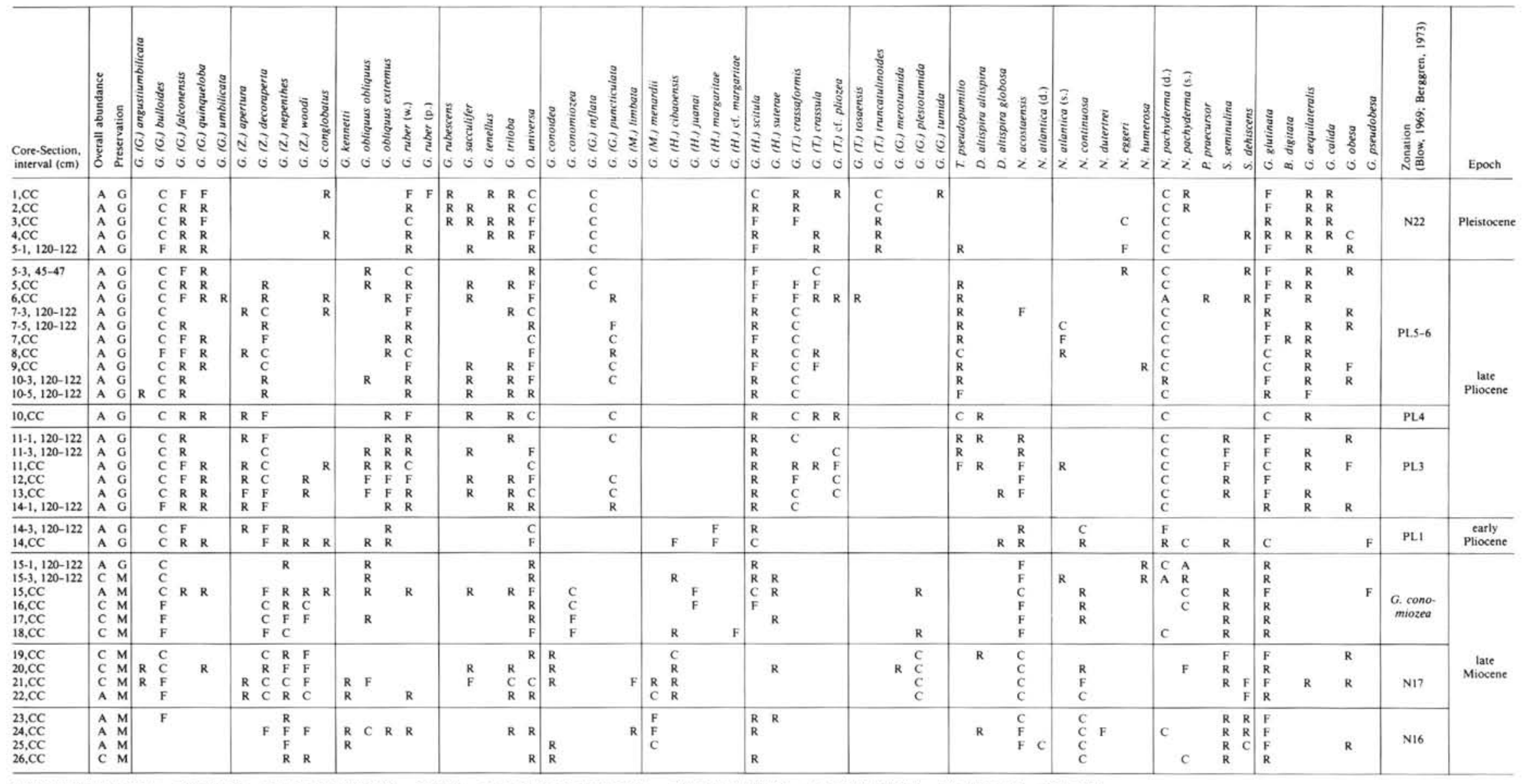

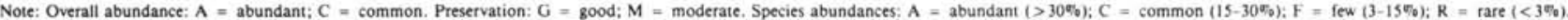


Table 7. Distribution of planktonic foraminifers, Hole 608A.

\begin{tabular}{|c|c|c|c|c|c|c|c|c|c|c|c|c|c|c|c|c|c|c|c|c|c|c|c|c|c|c|c|c|c|c|c|c|c|}
\hline $\begin{array}{l}\text { Core-Section, } \\
\text { interval }(\mathrm{cm})\end{array}$ & 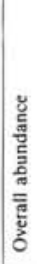 & 들 & 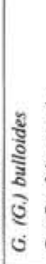 & 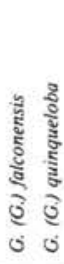 & 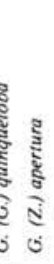 & 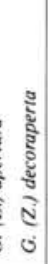 & 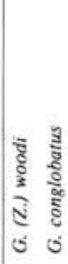 & 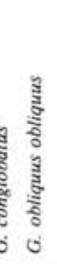 & 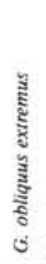 & 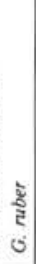 & $\begin{array}{ll}\text { है } & \text { ङ } \\
\text { हैँ } \\
\text { है } \\
ن \\
ن\end{array}$ & ט & 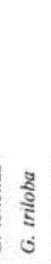 & $\begin{array}{l}8 \\
\frac{2}{5} \\
\text { है } \\
0\end{array}$ & ¿气 & 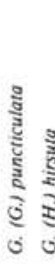 & 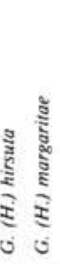 & 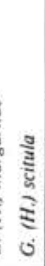 & 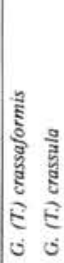 & 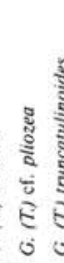 & 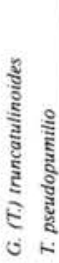 & 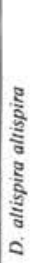 & $\begin{array}{l} \\
\text { है } \\
\text { ğ } \\
\text { हू } \\
z\end{array}$ & 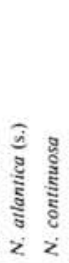 & $\frac{\bar{z}}{2}$ & 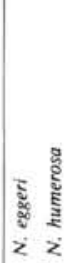 & 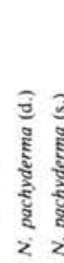 & 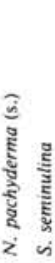 & 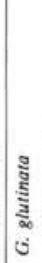 & 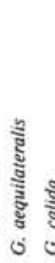 & $\begin{array}{ll}\text { छี้ } \\
\text { ฮู } \\
\text { ن } \\
ن\end{array}$ & 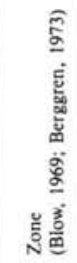 & Epoch \\
\hline $\begin{array}{l}1, \mathrm{CC} \\
2, \mathrm{CC} \\
3, \mathrm{CC} \\
4, \mathrm{CC} \\
\text { 5.CC }\end{array}$ & $\begin{array}{l}\text { A } \\
\text { A } \\
\text { A } \\
\text { A }\end{array}$ & $\begin{array}{l}\text { G } \\
\text { G } \\
\text { G } \\
\text { G } \\
\text { G }\end{array}$ & $\begin{array}{l}\mathrm{C} \\
\mathrm{C} \\
\mathrm{C} \\
\mathrm{C} \\
\mathrm{C}\end{array}$ & $\begin{array}{ll}R & C \\
R & C \\
R & F \\
R & R \\
R & R\end{array}$ & $\begin{array}{l}\mathrm{C} \\
\mathrm{C} \\
\mathrm{F} \\
\mathrm{R} \\
\mathrm{R}\end{array}$ & & $\mathrm{R}$ & & R & $\begin{array}{l}\mathrm{F} \\
\mathrm{R} \\
\mathrm{R} \\
\mathrm{C} \\
\mathrm{R}\end{array}$ & R & $\begin{array}{l}R \\
R\end{array}$ & & $\begin{array}{l}\mathrm{R} \\
\mathrm{R} \\
\mathrm{F} \\
\mathrm{F} \\
\mathrm{R}\end{array}$ & $\begin{array}{l}\mathrm{C} \\
\mathrm{C} \\
\mathrm{C} \\
\mathrm{C} \\
\mathrm{C}\end{array}$ & $\mathbf{R}$ & R & $\begin{array}{l}C \\
R \\
R \\
R \\
R\end{array}$ & $\begin{array}{ll}R & \\
F & R \\
& R\end{array}$ & & $\begin{array}{ll}C & \\
R & \\
R & \\
R & R \\
R & \end{array}$ & & & & $\begin{array}{l}R \\
R\end{array}$ & $\begin{array}{l}\text { C } \\
\text { F }\end{array}$ & $\begin{array}{ll}\mathrm{C} & \mathrm{R} \\
\mathrm{C} & \mathrm{R} \\
\mathrm{C} & \\
\mathrm{C} & \\
\mathrm{C} & \end{array}$ & & $\begin{array}{l}\mathrm{F} \\
\mathrm{F} \\
\mathrm{F} \\
\mathrm{F} \\
\mathrm{R}\end{array}$ & $\begin{array}{ll}R & R \\
R & R \\
R & R \\
R & R \\
R & \end{array}$ & $\begin{array}{l}\mathrm{R} \\
\mathrm{R} \\
\mathrm{R} \\
\mathrm{R}\end{array}$ & $\mathrm{N} 22$ & Pleistocene \\
\hline $\begin{array}{l}6, \mathrm{CC} \\
7, \mathrm{CC} \\
8, \mathrm{CC} \\
9, \mathrm{CC} \\
10, \mathrm{CC} \\
11, \mathrm{CC}\end{array}$ & $\begin{array}{l}\text { A } \\
\text { A } \\
\text { A } \\
\text { A } \\
\text { A }\end{array}$ & $\begin{array}{l}\text { G } \\
\text { G } \\
\text { G } \\
\text { G } \\
\text { G } \\
\text { G }\end{array}$ & $\begin{array}{l}\mathrm{C} \\
\mathrm{F} \\
\mathrm{C} \\
\mathrm{C} \\
\mathrm{C} \\
\mathrm{C}\end{array}$ & $\begin{array}{ll}F & R \\
R & R \\
F & R \\
R & R \\
R & \\
F & R\end{array}$ & $\begin{array}{ll}\mathrm{R} & \mathrm{R} \\
\mathrm{R} & \mathrm{R} \\
\mathrm{R} & \\
\mathrm{R} & \\
\mathrm{R} & \\
\mathrm{R} & \end{array}$ & $\begin{array}{l}\mathrm{F} \\
\mathrm{C} \\
\mathrm{C} \\
\mathrm{C} \\
\mathrm{F} \\
\mathrm{F}\end{array}$ & $\begin{array}{l}R \\
R \\
R\end{array}$ & $\begin{array}{l}\mathrm{R} \\
\mathrm{R}\end{array}$ & $\begin{array}{l}R \\
R \\
R \\
R \\
R\end{array}$ & $\begin{array}{l}\mathrm{F} \\
\mathrm{F} \\
\mathrm{C} \\
\mathrm{R} \\
\mathrm{R} \\
\mathrm{R}\end{array}$ & $\begin{array}{l}R \\
R\end{array}$ & & $\begin{array}{l}\mathrm{R} \\
\mathrm{R} \\
\mathrm{R} \\
\mathrm{R}\end{array}$ & $\begin{array}{l}F \\
F \\
F \\
F \\
R \\
F\end{array}$ & $\begin{array}{l}\text { cf. } \\
\text { cf. }\end{array}$ & $\begin{array}{l}\mathrm{R} \\
\mathrm{C} \\
\mathrm{C} \\
\mathrm{C} \\
\mathrm{C} \\
\mathrm{C}\end{array}$ & & $\begin{array}{l}\mathrm{R} \\
\mathrm{F} \\
\mathrm{R} \\
\mathrm{R} \\
\mathrm{R}\end{array}$ & \begin{tabular}{|ll}
$C$ & \\
$F$ & \\
$F$ & \\
$C$ & \\
$F$ & \\
$F$ & $C$
\end{tabular} & $\mathrm{~F}$ & $\begin{array}{l}R \\
R\end{array}$ & & $\begin{array}{ll}F & F \\
R & F\end{array}$ & $\begin{array}{l}\mathrm{R} \\
\mathrm{R} \\
\mathrm{R}\end{array}$ & & $R$ & $\begin{array}{l}\mathrm{C} \\
\mathrm{C} \\
\mathrm{F} \\
\mathrm{C} \\
\mathrm{C} \\
\mathrm{C}\end{array}$ & & $\begin{array}{l}\mathrm{C} \\
\mathrm{F} \\
\mathrm{F} \\
\mathrm{F} \\
\mathrm{R} \\
\mathrm{F}\end{array}$ & $\begin{array}{l}R \\
R \\
R \\
R \\
R \\
R\end{array}$ & $\begin{array}{l}R \\
R \\
R \\
R\end{array}$ & PL4-6 & $\begin{array}{c}\text { late } \\
\text { Pliocene }\end{array}$ \\
\hline $\begin{array}{l}12, \mathrm{CC} \\
13, \mathrm{CC} \\
14-1,120-122\end{array}$ & $\begin{array}{l}\mathrm{A} \\
\mathrm{A} \\
\mathrm{A}\end{array}$ & $\begin{array}{l}G \\
G \\
G\end{array}$ & $\begin{array}{l}\text { C } \\
\text { F } \\
\text { C }\end{array}$ & $\begin{array}{l}\mathbf{R} \\
\mathbf{R}\end{array}$ & $\begin{array}{ll}R & R \\
R & R \\
& R\end{array}$ & $\begin{array}{l}F \\
F \\
C\end{array}$ & & $\mathrm{R}$ & $\begin{array}{l}R \\
R \\
F\end{array}$ & $\begin{array}{l}\mathrm{C} \\
\mathrm{R} \\
\mathrm{F}\end{array}$ & $\begin{array}{l}R \\
R\end{array}$ & & $\begin{array}{l}\mathrm{R} \\
\mathrm{C} \\
\mathrm{R}\end{array}$ & $\begin{array}{l}\mathrm{F} \\
\mathrm{F} \\
\mathrm{R}\end{array}$ & & $\begin{array}{l}\mathrm{R} \\
\mathrm{C} \\
\mathrm{F}\end{array}$ & & $\begin{array}{l}\mathrm{R} \\
\mathrm{R} \\
\mathrm{R}\end{array}$ & F & $\begin{array}{l}\mathbf{R} \\
\mathrm{F} \\
\mathrm{F}\end{array}$ & R & & $\begin{array}{l}\mathrm{F} \\
\mathrm{F} \\
\mathrm{F}\end{array}$ & R & & & $\begin{array}{l}\mathrm{C} \\
\mathrm{C} \\
\mathrm{C}\end{array}$ & $\begin{array}{l}R \\
R \\
R\end{array}$ & $\begin{array}{l}F \\
F \\
R\end{array}$ & $\begin{array}{l}F \\
R \\
F\end{array}$ & & PL.3 & \\
\hline $\begin{array}{l}14-3,120-122 \\
14, C C \\
15, C C \\
16, C C\end{array}$ & $\begin{array}{l}\mathrm{A} \\
\mathrm{A} \\
\mathrm{A} \\
\mathrm{A}\end{array}$ & $\begin{array}{l}\mathrm{G} \\
\mathrm{G} \\
\mathrm{G} \\
\mathrm{M}\end{array}$ & $\begin{array}{l}\mathrm{C} \\
\mathrm{C} \\
\mathrm{C} \\
\mathrm{C}\end{array}$ & $\begin{array}{ll}R & \\
R & R \\
R & \\
& \end{array}$ & R & \begin{tabular}{l|}
$\mathrm{F}$ \\
$\mathrm{C}$ \\
$\mathrm{C}$ \\
$\mathrm{F}$
\end{tabular} & R & $\begin{array}{l}R \\
R \\
R\end{array}$ & $\begin{array}{l}R \\
R \\
F \\
F\end{array}$ & $\begin{array}{l}R \\
R \\
R\end{array}$ & $\mathbf{R}$ & & $\begin{array}{l}\mathrm{R} \\
\mathrm{R} \\
\mathrm{R}\end{array}$ & $\begin{array}{l}\mathrm{R} \\
\mathrm{F} \\
\mathrm{R} \\
\mathrm{F}\end{array}$ & & $\begin{array}{l}\text { C } \\
\text { R }\end{array}$ & $\begin{array}{l}\mathrm{R} \\
\mathrm{C} \\
\mathrm{F} \\
\mathrm{F}\end{array}$ & $\begin{array}{l}R \\
R \\
R \\
F\end{array}$ & $\begin{array}{l}\mathrm{F} \\
\mathrm{F} \\
\mathrm{R}\end{array}$ & $F$ & & & $\begin{array}{l}\mathrm{F} \\
\mathrm{F} \\
\mathrm{F} \\
\mathrm{C}\end{array}$ & C & & & $\begin{array}{l}\mathrm{C} \\
\mathrm{R} \\
\mathrm{C} \\
\mathrm{C}\end{array}$ & $\mathbf{R}$ & $\begin{array}{l}R \\
R \\
R \\
R\end{array}$ & R & $\begin{array}{l}\mathrm{R} \\
\mathrm{R} \\
\mathrm{R} \\
\mathrm{R}\end{array}$ & PL2 & $\begin{array}{c}\text { early } \\
\text { Pliocene }\end{array}$ \\
\hline
\end{tabular}

Note: Overall abundance: $\mathrm{A}=$ abundant. Preservation: $\mathrm{G}=$ good; $\mathrm{M}=$ moderate. Species abundance: $\mathrm{C}=$ common $(15-30 \%) ; \mathrm{F}=\mathrm{few}(3-15 \%) ; \mathrm{R}=\mathrm{rare}(<3 \%)$.

The cooler-water aspect of this site excludes some of the zonal species, and not all of Berggren's zones can be identified. Other subpolar species are more common, however, so the site provides a valuable link between the subtropical sites to the south and the subpolar sites to the north.

The base of Zone N22 lies in Cores 608-5 and 608A-6; zonal species $G$. truncatulinoides is rare in both holes, except in the uppermost samples. The most common species in this zone are $G$. inflata, G. bulloides, and $N$. pachyderma (d); subtropical species such as $G$. ruber are rare. Globorotalia hirsuta is present in Sample 608A-1,CC and pink $G$. ruber occurs in Sample 608-1,CC, suggesting topmost Quaternary. Neogloboquadrina eggeri occurs commonly near the base of the zone.

Zones PL5 and PL6 cannot be distinguished by the last occurrence of $G$. miocenica, since this species does not occur at this site. D. altispira, the Zone PL4 marker, is extremely rare and has been found in only two Pliocene cores, 608-10 and 608-11. The PL5/PL4 boundary lies between samples $608-10, C C$ and $608-105,120-122 \mathrm{~cm}$ (91-93.4 m), but cannot be identified in Hole 608A. At Sites 606 and 607, the transition from G. puncticulata to G. inflata occurs at approximately the PL5/PL6 boundary. The same transition occurs at Site 608 in Cores 6086 and 608-7 and 608A-6 and 608A-7, although very few specimens of either species were found in this interval. Apart from these changes, the fauna of Zones PL4 to PL6 is similar to that of Zone N22, with the addition of common $G$. decoraperta. The top of Zone PL3 is taken to be at the last occurrence of $S$. seminulina, and lies between Samples 608-11-1, 120-122 cm and 608-10,CC (93.4-94.6 m) and in Core 608A-12 (98.4-108 m).

Zone PL3 extends down to the last occurrence of $G$. margaritae, between samples 608-14-3, 120-122 cm and $608-14-1,120-122 \mathrm{~cm}(123-126 \mathrm{~m})$ and in Core 608A-14
(117.6-127.2 m). This zone also contains fairly common $G$. cf. crassula. Zone PL2 is present from Core 608A-14 to the base of Hole $608 \mathrm{~A}$, but was not found in Hole 608. This suggests a local hiatus within Core 608-14, which must be responsible for the removal of at least $19 \mathrm{~m}$ of sediment. This is rather surprising, since Holes 608 and $608 \mathrm{~A}$ are only $670 \mathrm{ft}$. apart; similar discrepancies occur, however, in the paleomagnetic data (Clement and Robinson, this volume) and the calcareous nannofossil data (Takayama and Sato, this volume). The first appearances of both $G$. puncticulata and $G$. crassaformis occur in Core 608A-16 (136.8-146.4 m), within Zone PL2.

Zone PL1, defined by the overlap of $G$. margaritae with $G$. nepenthes, occurs between Samples 608-14-1, 120$122 \mathrm{~cm}$ and 608-14,CC. According to Berggren (1977), Globorotalia cibaoensis is present only in the lowermost part of the Zone PL1. It occurs here in Sample 60814, CC, so the upper part of Zone PL1 may also be represented in the hiatus in this hole.

Samples $608-15$, CC to $608-19$, CC contain Globorotalia conomiozea, and are therefore placed in the late Miocene G. conomiozea Zone of Berggren (1977). Samples from this zone have suffered some dissolution, along with a reduction in the number of specimens and a slight reduction in the number of species, relative to samples above. Neogloboquadrina pachyderma (s), G. decoraper$\mathrm{ta}$, and $G$. bulloides are the most common species in this interval, together with $G$. conomiozea.

Globorotalia conoidea is not common at Site 608, so Berggren's (1977) G. conoidea Zone cannot be recognized. A late Miocene age for Cores 608-20 to 608-26 can, however, be determined on the basis of the presence of Neogloboquadrina acostaensis. Cores 608-19 through 608-22 contain common Globorotalia plesiotumida, the first appearance of which defines the base of Blow's Zone 
N17; below this, the absence of $G$. plesiotumida and the presence of $N$. acostaensis suggest Zone N16 of Blow (1969).

\section{Site 609 (Tables 8-10)}

Four holes were drilled at this site; in Holes 609 and 609B we recovered cores continuously to the upper Miocene. Holes $609 \mathrm{~A}$ and $609 \mathrm{C}$ cover coring gaps in the main holes in the upper Pleistocene and upper Pliocene, respectively.

The site lies at the southern end of the present-day subpolar gyre, and during glacial maxima it lay beneath polar surface water (Ruddiman and McIntyre, 1976). Glacial/interglacial differences are therefore extreme. Specimens are abundant through the upper Pliocene and Pleistocene but less common in some lower Pliocene and upper Miocene samples. Preservation is also much poorer in the upper Miocene, with very strong dissolution at some levels.

Species diversity is lower than at previous sites, and subtropical species such as $G$. sacculifer, D, altispira, and $S$. seminulina are virtually absent. The cool-water species Neogloboquadrina atlantica is, however, much more abundant here than at Sites 607 and 608 .

This site has had a very high rate of deposition, with up to $89 \mathrm{~m} / \mathrm{m}$.y. recorded for the early Pleistocene (Site 609 report, this volume). The deposition rates were considerably higher than production rates of carbonate in the area; extra material is thought to have been added by redistribution on the seafloor, and possibly by some volcaniclastic contribution from the nearby Maury Channel. Glacial debris from ice-rafting also contributed a significant component in the interval from $2.4 \mathrm{Ma}$ to Recent.

The scarcity or absence of many of the zonal markers makes Berggren's $(1973 ; 1977)$ zonation difficult to apply at this site. G. truncatulinoides is first recorded in Samples 609-13,CC (122.2 m) and 609B-13,CC (118.8 m), but it is very rare or absent in the samples immediately above, and so is an unreliable marker. Huddlestun (1985) regarded the first appearance of encrusted, sinistrally coiled N. pachyderma as an important marker in the lower Pleistocene, and Pujol and Duprat (1985) also recognized this increase. The importance of this form and its dramatic first appearance near the base of the Quaternary was shown by Poore and Berggren (1975; Fig. 4). It first appears in Samples 609-12,CC (112.6 m) and 609B$13, \mathrm{CC}(118.8 \mathrm{~m})$, close to the Pliocene/Pleistocene boundary. The upper part of Zone N22 is marked by the presence of G. hirsuta in Cores 609-1 and -2 and in Sample 609B-2,CC. The most common species in Zone N22 are Globigerina bulloides, G. quinqueloba, Globorotalia inflata, and $N$. pachyderma (d); the coldest glacial samples are dominated by $N$. pachyderma $(\mathrm{s})$. Sample 609B$8, \mathrm{CC}$ contains no fauna and consists exclusively of glacial debris. The two cores of Hole 609A belong to Zone N22.

Zones PL3 to PL6 cannot be distinguished, because of the absence of the zonal species at these latitudes. Recognizing this, Poore and Berggren (1975) erected a separate zonal scheme for the high-latitude North At- lantic. They used the successive first appearances of Globorotalia puncticulata, G. crassaformis, and G. inflata to subdivide the Pliocene. The G. inflata Zone can be recognized at Site 609, and, by comparison with sites to the south, may correlate with Zone PL6. The G. crassaformis and $G$. puncticulata zones, however, cannot be distinguished, since both species appear simultaneously near the top of the G. margaritae Zone. The first occurrence of $G$. inflata is in Samples 609-16,CC (149.8 m), 609B-16,CC (143.5 m), and 609C-1,CC (132.8 m), although a few forms transitional to $G$. puncticulata can be found below this level. As at previous sites, Neogloboquadrina eggeri occurs in this interval in the upper Pliocene and crosses into the Pleistocene. The last occurrence of $N$. atlantica is in Cores 609-19 (169.0-178.6 m), 609B-19 (162.7-172.3 m), and 609C-5 (161.6-171.2 m). This extinction was taken by Poore (1979) and Poore and Berggren (1975) to approximate the Pliocene/Pleistocene boundary, but data from this leg (Weaver and Clement, this volume) show that it is somewhat older and lies just below the base of the $G$. inflata Zone. A latest Pliocene age for this LAD has also been determined by Huddlestun (1985) and Pujol and Duprat (1985). There is thus, between the last occurrence of $N$. atlanti$c a$ (s) and the first occurrence of encrusted $N$. pachyder$m a$ (s), an interval with no sinistral Neogloboquadrina, which approximates to Poore and Berggren's $G$. inflata Zone. At the base of the interval from PL3 to PL6, $G$. cf. crassula can be found in cores 609-26 and 609-27 and 609B-26 to 609B-28. At sites to the south, this occurrence of $G$. cf. crassula correlated with Zone PL3. The most common species in the interval from PL3 to PL6 are G. bulloides, G. inflata/G. puncticulata, and $N$. pachyderma (d). The base of Zone PL3 is taken to be at the last occurrence of G. margaritae in Samples 60929-3, 118-120 cm and 609B-29, CC.

Zone PL2 is relatively short at this site. It extends down to Samples 609-30-5, 120-122 cm (281.8 m) and 609B-30,CC $(277.9 \mathrm{~m})$. The fauna is similar to that in the overlying interval, but in Hole 609 G. puncticulata and G. crassaformis are absent. Zone PL1 extends to Samples 609-36,CC (341.8 m) and 609B-35,CC (325.9 m), but both $G$. nepenthes and $G$. margaritae are rare and probably at the northern limit of their ranges. N. pachyderma is the dominant species in Zone PL1; its relative abundance may possibly have been increased by moderate dissolution. This species is coiled dextrally in the upper part of the zone and sinistrally at the base. This sinistral form of $N$. pachyderma is not encrusted, and thus differs from the Pleistocene specimens. The base of Zone PL1 is taken at the first occurrence of G. margaritae, and is therefore not directly equivalent to Zone PL1 as defined by Berggren. Below this zone there is severe dissolution, with considerably reduced faunas and many broken specimens. In Sample 609-41,CC, dissolution is so severe that the fauna consists of a nearly monospecific assemblage of heavily encrusted Globorotalia conoidea. The presence of $N$. atlantica (s) down to Sample $609-40, \mathrm{CC}$ and the base of Hole 609B suggests a latest Miocene age for this interval. Sample $609-42$, CC contains dextrally coiled $N$. atlantica, so the coiling-direc- 


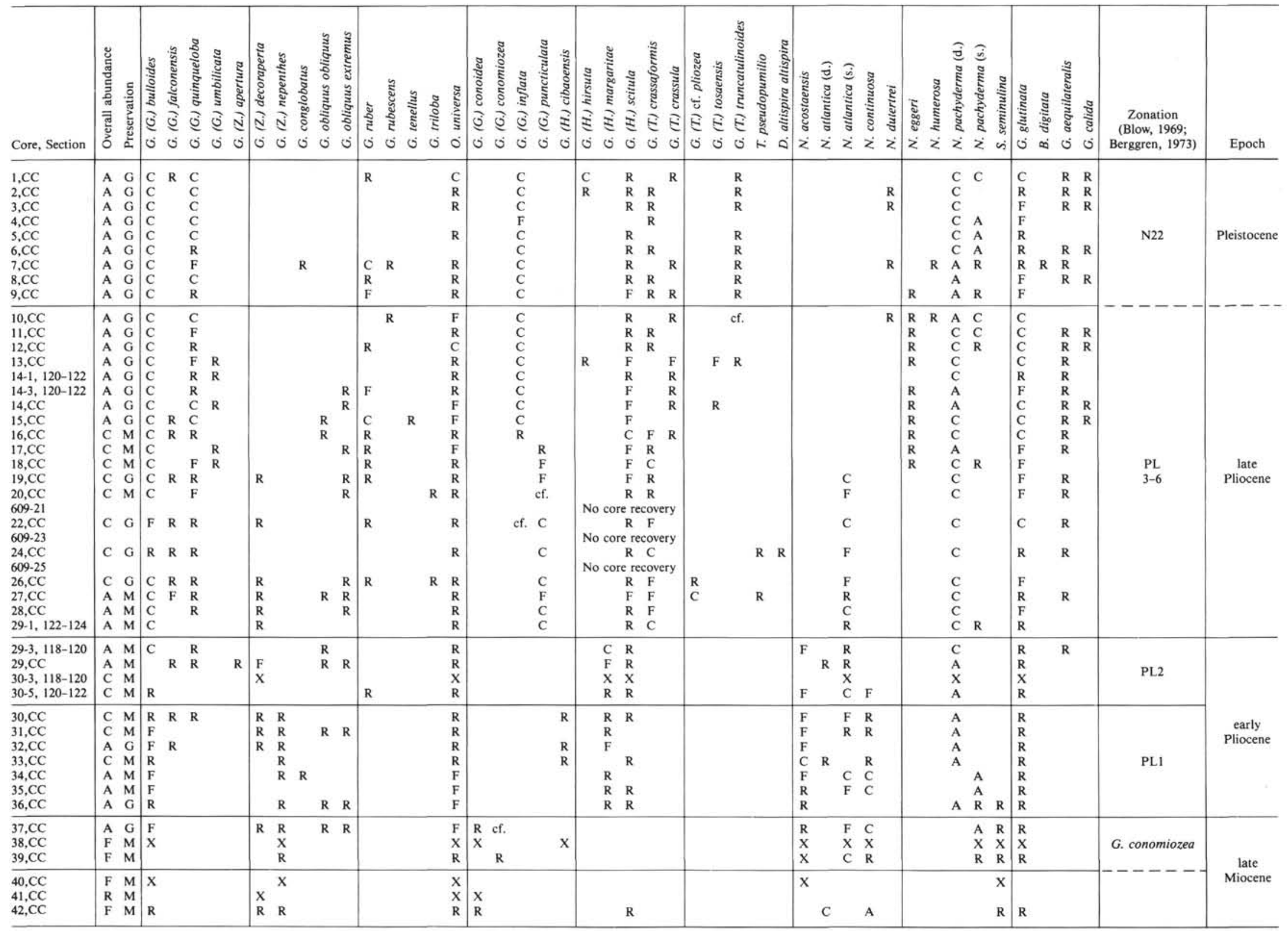

Note: Overall abundance: $\mathrm{A}=$ abundant $\mathrm{C}=$ common; $\mathrm{F}=$ few; $\mathrm{R}=$ rare. Preservation: $\mathrm{G}=$ good; $\mathrm{M}=$ moderate. Species abundance: $\mathrm{A}=\operatorname{abundant}(>30 \%) ; \mathrm{C}=$ common $(15-30 \%) ; \mathrm{F}=$ few $(3-15 \%) ; \mathrm{R}=$ rare $(<3 \%) ; \mathrm{X}=$ fauna too poorly preserved for an estimate. 
Table 9. Distribution of planktonic foraminifers, Hole 609B.

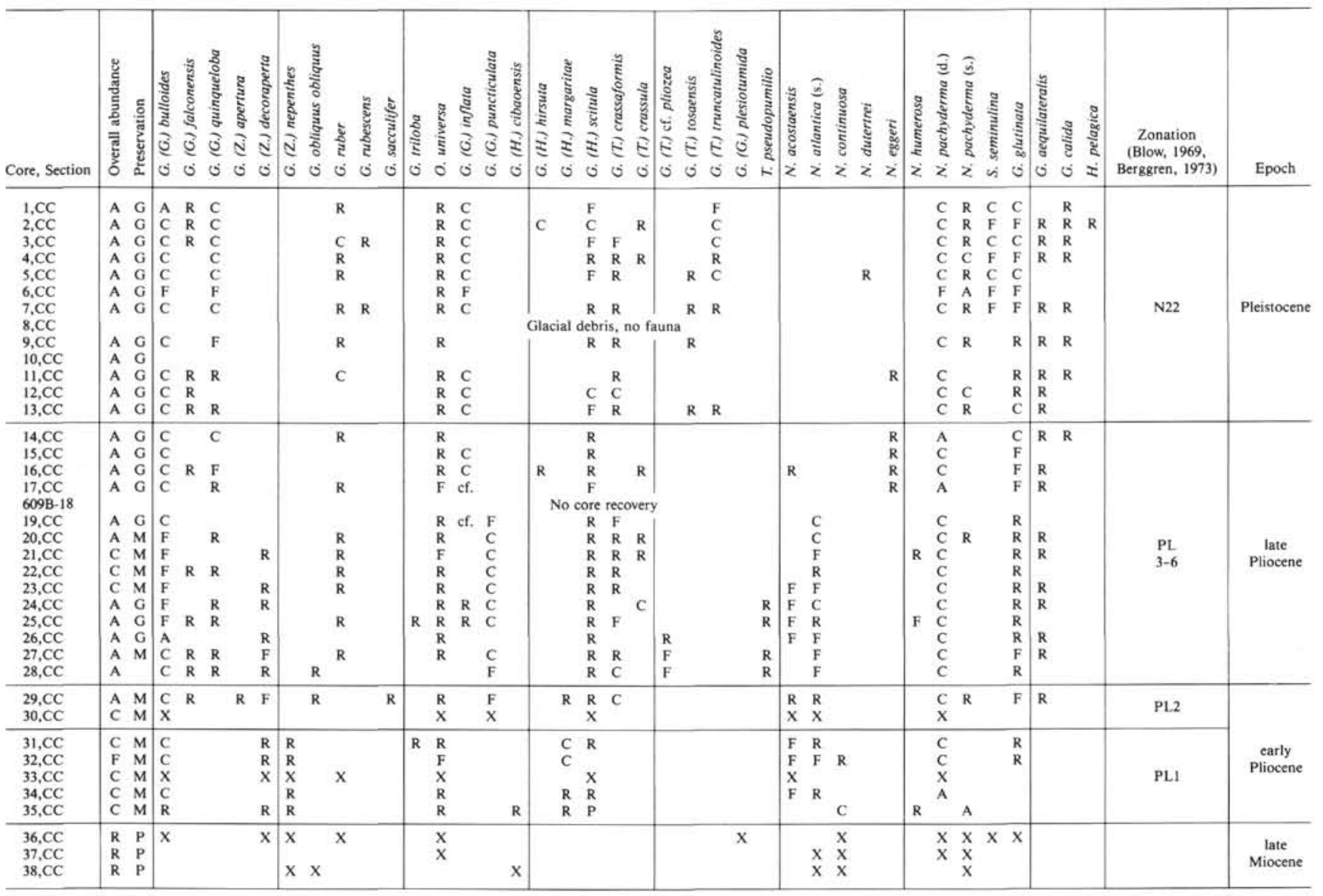

Note: Overall abundance: $\mathrm{A}=$ abundant; $\mathrm{C}=$ common; $\mathrm{F}=$ few; $\mathrm{R}=$ rare. Preservation: $\mathrm{G}=$ good; $\mathrm{M}=$ moderate; $\mathrm{P}=$ poor. Species abundance: $\mathrm{A}=\mathrm{abundant}(>30 \%) ; \mathrm{C}=$ common $(15-30 \%) ; \mathrm{F}=$ few $(3-15 \%): R=$ rare $(<3 \%) ; X=$ fauna too poorly preserved for an estimate.

Table 10. Distribution of planktonic foraminifers, Holes 609A and $609 \mathrm{C}$.

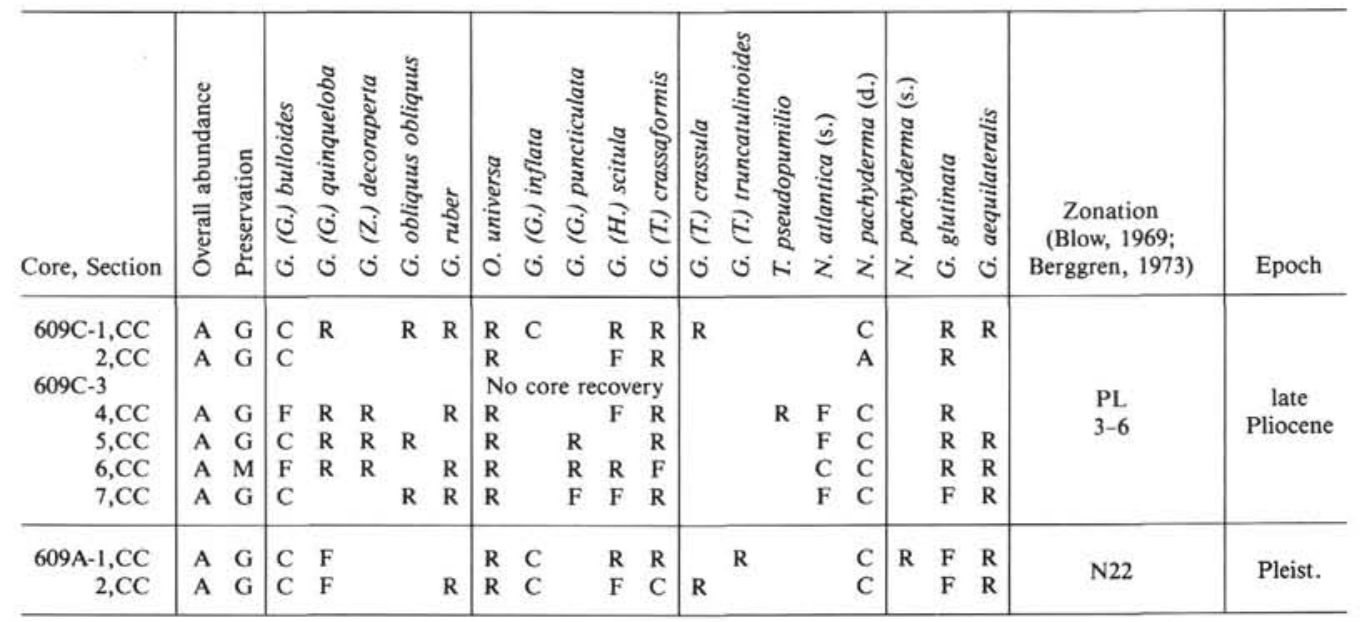

Note: Overall abundance: $\mathrm{A}=$ abundant. Preservation: $\mathrm{G}=\operatorname{good} ; \mathrm{M}=$ moderate. Species abundance: $\mathrm{A}=$ abundant $(>30 \%) ; \mathrm{C}=$ common $(15-30 \%) ; \mathrm{F}=$ few $(3-15 \%) ; \mathrm{R}=\operatorname{rare}(<3 \%)$.

tion change in this species must occur in Core $609-41$ or Core 609-42. Poore (1979) regarded this change as marking the Miocene/Pliocene boundary, but Weaver and Clement (this volume) show, on paleomagnetic evidence, that it occurred in the late Miocene.
Site 610 (Tables 11 and 12)

The primary objective at this site was to study the formation of Feni Ridge sediment drift. Six holes were drilled, $610,610 \mathrm{~A}, 610 \mathrm{~B}$, and $610-\mathrm{C}$ on the crest of a 
Table 11. Distribution of planktonic foraminifers, Holes 610 and $610 \mathrm{~A}$

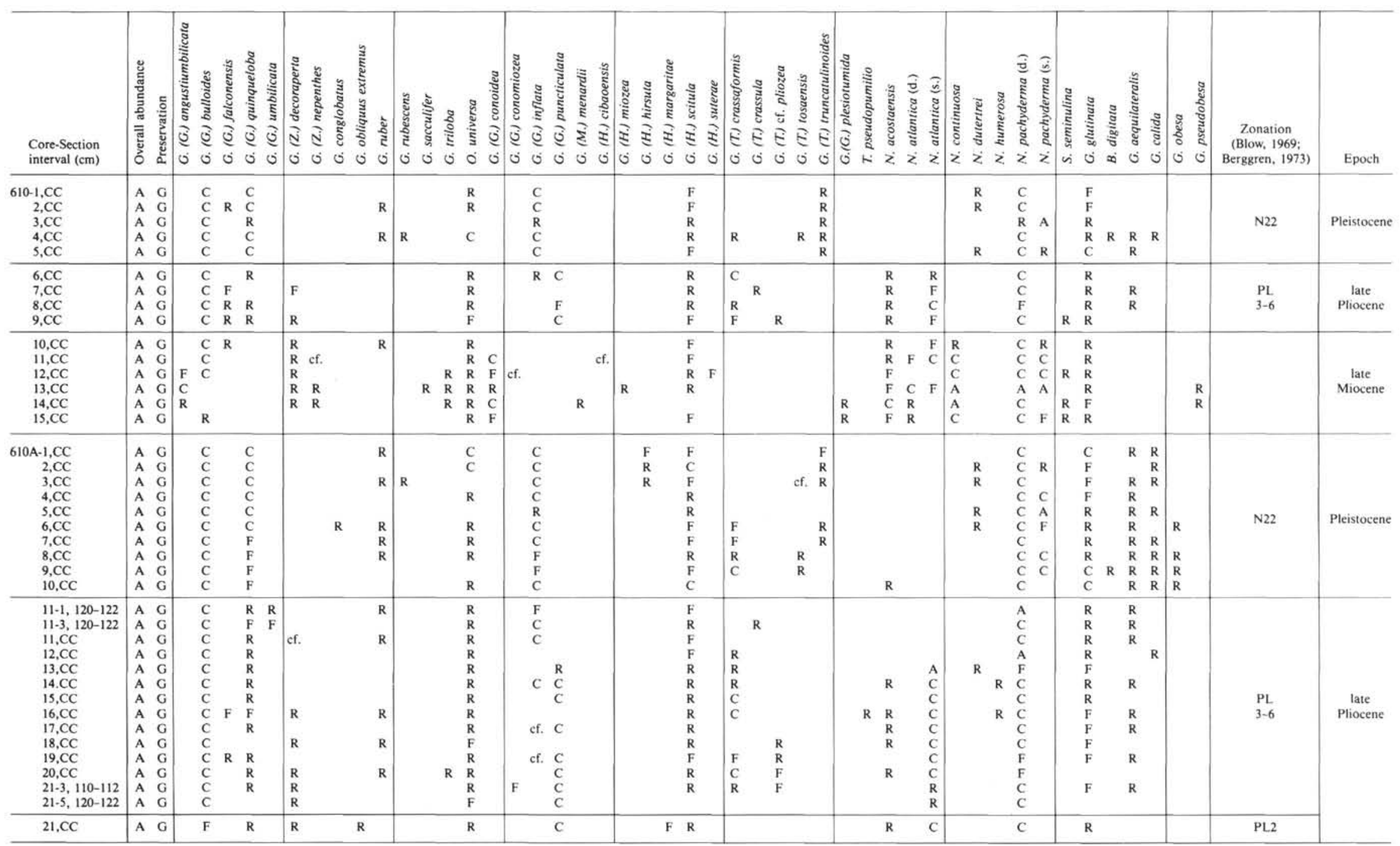

Note: Overall abundance: $\mathbf{A}=$ abundant. Preservation: $\mathrm{G}=$ good. Species abundance: $\mathrm{A}=$ abundant $(>30 \%) ; \mathrm{C}=$ common $(15-30 \%) ; \mathrm{F}=$ few $(3-15 \%) ; \mathrm{R}=\operatorname{rare}(<3 \%)$. 
Table 12. Distribution of planktonic foraminifers, Holes 610B, 610C, 610D, and 610E.

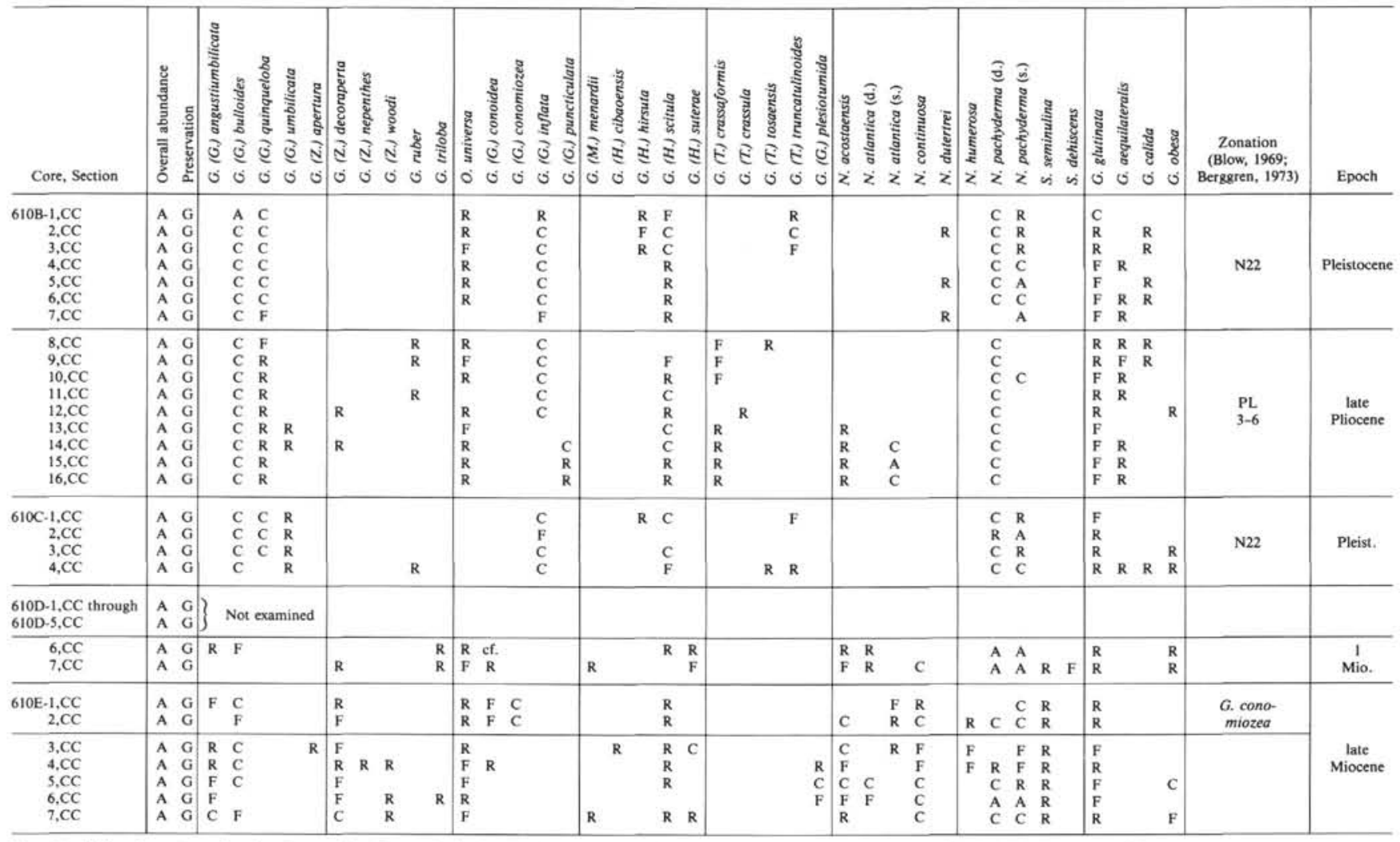

Note: Overall abundance: $\mathbf{A}=$ abundant. Preservation: $\mathrm{G}=\mathrm{g} 0 \mathrm{~d}$. Species abundance: $\mathbf{A}=$ abundant $(>30 \%) ; \mathrm{C}=$ common $(15-30 \%) ; \mathrm{F}=$ few $(3-15 \%) ; \mathrm{R}=\mathrm{rare}(\langle 3 \%)$.

large sediment wave, $610 \mathrm{D}$ and $610 \mathrm{E}$ in the adjacent trough. It was expected that sedimentation rates at this site would have been higher than average, with material being transported in to build the drift. As at the previous sites, however, little evidence of reworking was found, and the site therefore provides a good stratigraphic section.

The site lies under the present-day subpolar gyre, and was well north of the polar front during glacial maxima (Ruddiman and McIntyre, 1976). The fauna has a coolwater aspect, with good preservation from the upper Miocene to Recent.

Globorotalia truncatulinoides is not common at this site and is not present in all samples. It therefore cannot be used to define Zone N22. Neogloboquadrina pachyderma (s) occurs more consistently-with a first appearance in Samples 610-5,CC (48.0 m), 610A-10,CC (95.4 m), and $610 \mathrm{~B}-10, \mathrm{CC}(91.2 \mathrm{~m})$ - and may be a more reliable zonal fossil at this locality. Globorotalia hirsuta indicates the top of Zone N22 in Samples 610A-1, CC to $610 \mathrm{~A}-3, \mathrm{CC}, 610 \mathrm{~B}-1, \mathrm{CC}$ to $610 \mathrm{~B}-3, \mathrm{CC}$, and $610 \mathrm{C}-1, \mathrm{CC}$. Zone N22 contains common $G$. bulloides, $G$. quinqueloba, G. inflata, and N. pachyderma (d); glacial samples are dominated by $N$. pachyderma (s).

The zonal species for Zones PL3 to PL6 do not occur at this site, so these zones cannot be distinguished. Within this interval, however, $N$. atlantica becomes extinct between Cores 610-5 and 610-6 and in Cores 610A-13 (114.6-124.2 m) and 610B-14 (118-127.6 m). The transition from $G$. puncticulata to $G$. inflata also occurs between Cores 610A-12 and 610A-13 and between 610B-13 and 610B-14. Globorotalia cf. crassula occurs rarely at this site, but is present in Cores $610 \mathrm{~A}-18$ to $610 \mathrm{~A}-20$ and in Core 610-9. In addition, the fauna of this interval contains common $G$. bulloides and $N$. pachyderma (d), with $G$. scitula and $G$. crassaformis also common in some samples. The base of this interval-top of Zone PL2is marked by the extinction of G. margaritae. This occurs in Sample 610A-21,CC, but was not cored in the other holes at this site. Neither Zone PL2 nor Zone PL1 was recognized in Hole 610; these zones presumably lie in the washed interval between Cores 610-9 and 610-10.

It has proved difficult to subdivide the late Miocene. G. conomiozea occurs in Samples 610E-1 and 610E-2,CC, suggesting a $G$. conomiozea zonal age for these samples. Below this, Cores $610 \mathrm{E}-3$ to $610 \mathrm{E}-7$ and $610 \mathrm{D}-6$ and 610D-7 contain $G$. conoidea and $N$. acostaensis, indicating a late Miocene age. Neogloboquadrina atlanti$c a$ changes its coiling direction between Samples 610E$3, \mathrm{CC}$ and $610 \mathrm{E}-5, \mathrm{CC}$, and this change does not mark the Miocene/Pliocene boundary as was suggested by Berggren (1972) and Poore (1979).

In Hole 610 samples neither Globorotalia margaritae nor Globorotalia conomiozea has been found, so the $G$. conomiozea Zone cannot be recognized. Globorotalia conoidea, however, occurs in Samples 610-11,CC to 610$14, \mathrm{CC}$; the first appearance of N. acostaensis is in Sample $610-15, C C$. All these samples may belong to the $N$. acostaensis Zone, with the middle/upper Miocene boundary in Core 610-16. The coiling-direction change in $N$. atlantica occurs in the washed interval between Cores 
610-11 and 610-12. The fauna of the upper Miocene contains common to abundant $N$. pachyderma (d and s), together with common $G$. bulloides and sporadically common Neogloboquadrina acostaensis, $N$. continuo$s a$, and $G$. conoidea. There is very little dissolution at this site.

\section{Site 611 (Tables 13-15)}

Six holes were drilled: $611,611 \mathrm{~A}, 611 \mathrm{D}$, and $611 \mathrm{E}$ on the crest of a mudwave and 611B and 611C in the adjacent trough. As at Site 610, deposition rates were higher than productivity rates, but there is little evidence of reworking. The site lies in the subpolar gyre today, and was under polar water during glacials. Faunal composition here is similar to that at Site 610, with some dissolution in the lower Pliocene and upper Miocene.

Globorotalia truncatulinoides occurs too rarely to mark the Pliocene/Pleistocene boundary, but $N$. pachyderma (s) is more common, first appearing in Samples 611-7,CC $(58.6 \mathrm{~m}), 611 \mathrm{~A}-7, \mathrm{CC}(64.8 \mathrm{~m})$, and $611 \mathrm{C}-10, \mathrm{CC}(79.6 \mathrm{~m})$. Uppermost Pleistocene is indicated by the presence of G. hirsuta in Samples 611-1,CC, 611A-1,CC, 611C-1 to 611C-3,CC and 611E-1 and 611E-2,CC. The fauna of this interval contains common $G$. bulloides, G. quinqueloba, G. inflata, and N. pachyderma (d) in interglacials, but is dominated by $N$. pachyderma (s) in glacials.

This site is too far north for the occurrence of most of the PL zonal markers, except for G. margaritae. Zones PL3 to PL6 are therefore grouped together. Within this Zone PL3-Zone PL6 interval, the transition from $G$. puncticulata to G. inflata occurs between Samples 611$10, C C$ and 611-13,CC, between Samples 611A-9,CC and 611A-11, CC, and in Core 611C-13. The extinction of $N$. atlantica is in Cores 611-13 (106.6-116.2 m), 611A-11 (93.6-103.2 m), 611C-14 (108.4-118.0 m), and 611D-2 $(128.9-138.5 \mathrm{~m})$. The most common species in this interval are $G$. bulloides, G. puncticulata, N. atlantica, and $N$. pachyderma (d). The base of Zone PL3 is determined by the extinction of G. margaritae in Sample 611C24-1, 120-122 cm (205.61 m) and in Core 611D-14 (234.5$244.1 \mathrm{~m})$. Globorotalia margaritae is very rare and overlaps with $G$. puncticulata and $G$. crassaformis for a very short interval near the top of its range. The base of Zone PL2 lies between Samples 611C-29,CC and 611C-29-5, $110-112 \mathrm{~cm}(259.5-262 \mathrm{~m})$. The most common species in Zone PL2 are G. bulloides, N. atlantica, and N. pachyderma $(\mathrm{d})$.

There is a short overlap of G. nepenthes and G. margaritae, indicating Zone PL1 in Samples 611C-29,CC and $611 \mathrm{C}-30, \mathrm{CC}(262-271.6 \mathrm{~m})$, although both species are very rare and obviously at the northern limit of their geographic ranges. Cores $611 \mathrm{C}-31$ to $611 \mathrm{C}-37$ contain neither $G$. margaritae nor $G$. conomiozea, and are therefore difficult to date. The most common species are $G$. bulloides, $N$. atlantica, and $N$. pachyderma; the latter species is dextrally coiled in Cores $611 \mathrm{C}-31$ to $611 \mathrm{C}-33$ and sinistrally coiled in Cores $611 \mathrm{C}-35$ to $611 \mathrm{C}-37$. Neogloboquadrina continuosa also occurs in this interval, becoming extinct above Sample 611C-31-1, 120-122 cm.

Cores $611 \mathrm{C}-38$ to $611 \mathrm{C}-40$ contain $G$. conomiozea, and are assigned to the $G$. conomiozea Zone. These sam- ples contain abundant $N$. pachyderma (s), together with common $N$. atlantica (s), but this assemblage may be the result, in part, of fairly strong dissolution. Below Core $611 \mathrm{C}-40$, to the base of the hole, the cores are assigned to the $N$. acostaensis Zone on the basis of the presence of $N$. acostaensis and the absence of $G$. conomiozea.

The fauna of the $N$. acostaensis Zone has again suffered varying degrees of dissolution; specimens are very rare in some intervals (e.g., Sample 611C-41,CC). This zone is dominated by Neogloboquadrina, with N. pachyderma (s) common in the upper part of the zone and $N$. pachyderma (d) common in Core $611 \mathrm{C}-44$ and below. Neogloboquadrina atlantica is sinistrally coiled down to Core $611 \mathrm{C}-42$ and dextrally coiled below.

\section{ZONATION}

\section{Upper Miocene}

The upper Miocene spans 6.2 m.y. (5.3-11.5 Ma), according to Berggren et al. (in press), but is very difficult to subdivide into a usable zonation at the Leg 94 North Atlantic sites. The problem results in part from dissolution, which has affected samples to varying degrees throughout this interval and has almost completely destroyed the planktonic foraminifers at some levels. The effect of dissolution is to remove the solution-susceptible species, thus increasing the proportion of more solution-resistant species, such as species of Neogloboquadrina. This not only reduces the number of potential stratigraphically useful species, but also makes any paleoecological conclusions unreliable. Dissolution has been most active during the Messinian ( 6.3-5.5 Ma).

In addition to the problems of dissolution, relatively few stratigraphically useful species are present in the upper Miocene. Thus, Blow (1969) created three zones, Kennett (1973) three zones, and Stainforth et al. (1975) one zone for this interval. More recently, Berggren et al (1983) have defined a South Atlantic upper Miocene zonation based on the sequential first appearance datums (FADs) of Neogloboquadrina acostaensis, Globorotalia conomiozea, G. cibaoensis, G. margaritae s.l., and the LAD of Globoquadrina dehiscens. G. dehiscens is very rare at the Leg 94 sites and G. margaritae s.l. has a very erratic first appearance, so only two of Berggren's intervals can be determined: a lower $N$. acostaensis Zone, with the base defined by the FAD of $N$. acostaensis and the top by the FAD of G. conomiozea, and a shorter G. conomiozea Zone between the FADs of $G$. conomiozea and $G$. margaritae s.s. (the typical form of G. margaritae is more common than the primitive forms).

The G. conomiozea Zone is not always easily recognizable, owing to the sporadic distribution of this species-it has not been found at all at Site 607, even though this site is well within its geographic range as delineated by Berggren (1984; Fig. 2). Bolli and Saunders (in press) subdivide the upper Miocene into two zones, a lower $N$. acostaensis Zone and an upper $N$. humerosa Zone. Neogloboquadrina humerosa is, however, a tropical species (Kennett and Srinivasan, 1983), and is very rare at the Leg 94 sites. Thus, a subdivision of the upper Miocene 
Table 13. Distribution of planktonic foraminifers, Holes 611, 611A, and 611B.

\begin{tabular}{|c|c|c|c|c|c|c|c|c|c|c|c|c|c|c|c|c|c|c|c|c|c|c|c|}
\hline Core, Section & 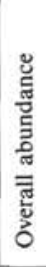 & : & 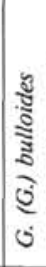 & 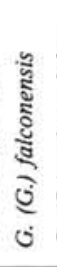 & نे & ऐั & 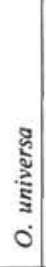 & 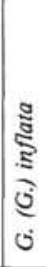 & 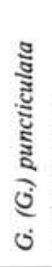 & ن & 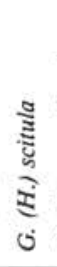 & 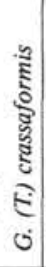 & 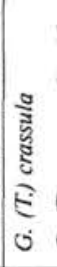 & 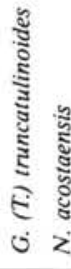 & 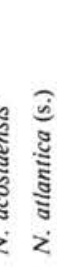 & 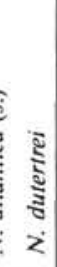 & $\begin{array}{l} \\
\vdots \\
\vdots \\
z \\
z\end{array}$ & 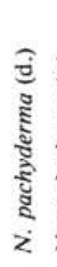 & 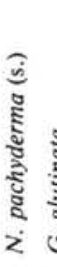 & 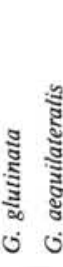 & : & $\begin{array}{c}\text { Zonation } \\
\text { (Blow, 1969; } \\
\text { Berggren, 1973) }\end{array}$ & Epoch \\
\hline $\begin{array}{r}611-1, C C \\
2, C C \\
3, C C \\
4, C C \\
5, C C \\
6, C C \\
7, C C \\
8, C C\end{array}$ & $\begin{array}{l}\text { A } \\
\text { A } \\
\text { A } \\
\text { A } \\
\text { A } \\
\text { A } \\
\text { C } \\
\text { C }\end{array}$ & $\begin{array}{l}\text { G } \\
\text { G } \\
\text { G } \\
\text { G } \\
\text { G } \\
\text { G } \\
\text { G } \\
\text { G }\end{array}$ & $\begin{array}{l}\text { C } \\
\text { C } \\
\text { C } \\
\text { F } \\
\text { C } \\
\text { C } \\
\text { C }\end{array}$ & & $\begin{array}{l}\mathrm{C} \\
\mathrm{C} \\
\mathrm{F} \\
\mathrm{R} \\
\mathrm{C} \\
\mathrm{C}\end{array}$ & $\mathbf{R}$ & R & $\begin{array}{l}\mathrm{C} \\
\mathrm{R} \\
\mathrm{C} \\
\mathrm{R} \\
\mathrm{F} \\
\mathrm{C} \\
\mathrm{C} \\
\mathrm{C}\end{array}$ & & R & $\begin{array}{l}\mathrm{R} \\
\mathrm{R} \\
\mathrm{R} \\
\mathrm{C}\end{array}$ & $\begin{array}{l}\mathrm{R} \\
\mathrm{F} \\
\mathrm{F}\end{array}$ & cf. & $\begin{array}{l}\mathrm{R} \\
\mathrm{R}\end{array}$ & & R & R & $\begin{array}{l}C \\
C \\
C \\
C \\
C \\
C \\
C\end{array}$ & $\begin{array}{ll}R & F \\
& F \\
R & F \\
A & F \\
C & F \\
C & F \\
C & 5 \\
& F\end{array}$ & $\begin{array}{ll}R & R \\
R & \\
R & \\
R & \\
R & \\
F & R \\
C & \\
R & R\end{array}$ & $\begin{array}{l}\mathrm{R} \\
2 \\
2\end{array}$ & $\mathrm{~N} 22$ & Pleistocene \\
\hline $\begin{array}{l}9, \mathrm{CC} \\
10, \mathrm{CC} \\
11, \mathrm{CC} \\
12, \mathrm{CC} \\
13, \mathrm{CC} \\
14, \mathrm{CC}\end{array}$ & $\begin{array}{l}\mathrm{A} \\
\mathrm{C} \\
\mathrm{A} \\
\mathrm{A} \\
\mathrm{A} \\
\mathrm{R}\end{array}$ & $\begin{array}{l}\mathrm{G} \\
\mathrm{G} \\
\mathrm{G} \\
\mathrm{G} \\
\mathrm{G} \\
\mathrm{M}\end{array}$ & $\begin{array}{l}C \\
C \\
X \\
F \\
C \\
X\end{array}$ & R & $\begin{array}{l}\mathrm{C} \\
\mathrm{R} \\
\mathrm{X} \\
\mathrm{R} \\
\mathrm{R}\end{array}$ & $\mathrm{R}$ & $\begin{array}{l}X \\
R \\
R\end{array}$ & $\begin{array}{l}\mathrm{R} \\
\mathrm{R}\end{array}$ & $\begin{array}{l}\mathrm{X} \\
\mathrm{R} \\
\mathrm{X}\end{array}$ & $\begin{array}{l}\mathrm{F} \\
\mathrm{X}\end{array}$ & $\begin{array}{l}\mathrm{C} \\
\mathrm{F} \\
\mathrm{F} \\
\mathrm{R}\end{array}$ & $\begin{array}{l}X \\
R \\
R\end{array}$ & & & $\begin{array}{l}\text { A } \\
\text { A } \\
\text { A }\end{array}$ & $\mathrm{R}$ & & $\begin{array}{l}\mathrm{C} \\
\mathrm{C} \\
\mathrm{X} \\
\\
\mathrm{x}\end{array}$ & $\begin{array}{ll} & \mathrm{F} \\
\mathrm{R} & \\
\mathrm{X} & \boldsymbol{X} \\
\mathrm{R} & \mathrm{F} \\
& \mathrm{I} \\
& X\end{array}$ & $\begin{array}{l}F \\
X \\
R \\
F \\
X\end{array}$ & & $\begin{array}{l}\text { PL } \\
3-6\end{array}$ & $\begin{array}{c}\text { late } \\
\text { Pliocene }\end{array}$ \\
\hline $\begin{array}{r}611 \mathrm{~A}-1, \mathrm{CC} \\
2, \mathrm{CC} \\
3, \mathrm{CC} \\
4, \mathrm{CC} \\
5, \mathrm{CC} \\
6, \mathrm{CC} \\
7, \mathrm{CC}\end{array}$ & $\begin{array}{l}\text { A } \\
\text { A } \\
\text { R } \\
\text { A } \\
\text { F } \\
\text { A } \\
\text { A }\end{array}$ & $\begin{array}{l}\text { G } \\
\text { G } \\
\text { G } \\
\text { G } \\
\text { M } \\
\text { G } \\
\text { G }\end{array}$ & $\begin{array}{l}\mathrm{C} \\
\mathrm{F} \\
\mathrm{C} \\
\mathrm{C} \\
\mathrm{C} \\
\mathrm{C}\end{array}$ & R & $\begin{array}{l}\mathrm{C} \\
\mathrm{X} \\
\mathrm{R} \\
\mathrm{C}\end{array}$ & $\begin{array}{l}X \\
R\end{array}$ & $\mathbf{R}$ & $\begin{array}{l}\mathrm{C} \\
\mathrm{F} \\
\mathrm{C} \\
\mathrm{X} \\
\mathrm{C} \\
\mathrm{C}\end{array}$ & $\mathbf{R}$ & R & $\begin{array}{l}\mathrm{F} \\
\mathrm{R} \\
\mathrm{R} \\
\mathrm{R}\end{array}$ & $\begin{array}{l}R \\
X \\
R\end{array}$ & R & $\begin{array}{ll} & \\
& \\
\text { cf. }\end{array}$ & & & $\mathbf{R}$ & $\begin{array}{l}\mathrm{C} \\
\mathrm{F} \\
\mathrm{C} \\
\mathrm{X} \\
\mathrm{C} \\
\mathrm{C}\end{array}$ & $\begin{array}{ll}\mathrm{C} & \mathrm{F} \\
\mathrm{A} & \mathrm{I} \\
\mathrm{X} & \\
\mathrm{C} & \mathrm{F} \\
\mathrm{X} & \\
\mathrm{F} & \\
\mathrm{C} & \mathrm{F}\end{array}$ & $\begin{array}{ll}R & R \\
F & \\
R & R \\
R & \\
R & R\end{array}$ & $\begin{array}{ll}R \\
R\end{array}$ & $\mathrm{~N} 22$ & Pleistocene \\
\hline $\begin{array}{l}8, \mathrm{CC} \\
9, \mathrm{CC} \\
10, \mathrm{CC} \\
11, \mathrm{CC} \\
12, \mathrm{CC} \\
13, \mathrm{CC}\end{array}$ & $\begin{array}{l}\text { A } \\
\text { R } \\
\text { A } \\
\text { F } \\
\text { A } \\
\text { A }\end{array}$ & $\begin{array}{l}\text { G } \\
P \\
G \\
\text { G } \\
\text { G } \\
\text { G }\end{array}$ & $\begin{array}{l}C \\
X \\
C \\
X \\
C \\
C\end{array}$ & & $\begin{array}{l}R \\
X \\
R\end{array}$ & $\mathbf{R}$ & $\begin{array}{l}\mathrm{F} \\
\mathrm{R}\end{array}$ & $\begin{array}{l}C \\
X\end{array}$ & $\begin{array}{l}\mathrm{X} \\
\mathrm{R} \\
\mathrm{C}\end{array}$ & & $\begin{array}{l}\mathrm{F} \\
\mathrm{X} \\
\mathrm{F} \\
\mathrm{X} \\
\mathrm{R} \\
\mathrm{R}\end{array}$ & $\begin{array}{l}\mathbf{R} \\
\mathbf{R} \\
\mathbf{R}\end{array}$ & $\mathrm{R}$ & $\begin{array}{l}\mathrm{R} \\
\mathrm{R}\end{array}$ & $\begin{array}{l}\text { A } \\
\text { A } \\
\text { C }\end{array}$ & & & $\begin{array}{l}\mathrm{C} \\
\mathrm{X} \\
\mathrm{A} \\
\mathrm{X} \\
\mathrm{R} \\
\mathrm{C}\end{array}$ & R & $\begin{array}{ll}\mathrm{R} & \\
\mathrm{R} & \mathrm{R}\end{array}$ & & $\begin{array}{l}\text { PL } \\
3-6\end{array}$ & $\begin{array}{c}\text { late } \\
\text { Pliocene }\end{array}$ \\
\hline $611 \mathrm{~B}-1, \mathrm{CC}$ & A & G & C & & C & & & C & & & & $\mathbf{R}$ & & & & $\mathrm{R}$ & & $\mathrm{R}$ & $C \mathrm{~F}$ & $\mathrm{R}$ & & $\mathrm{N} 22$ & Pleist. \\
\hline
\end{tabular}

Note: Overall abundance; $\mathrm{A}=$ abundant $\mathrm{C}=$ common; $\mathrm{F}=$ few; $\mathrm{R}=$ rare. Preservation: $\mathrm{G}=$ good; $\mathrm{M}=$ moderate. Species abundance: $\mathrm{A}=$ abundant $(>30 \%) ; \mathrm{C}=$ common $(15-30 \%) ; \mathrm{F}=$ few $(3-15 \%) ; \mathrm{R}=$ rare $(<3 \%) ; \mathrm{X}=$ fauna too poorly preserved for an estimate.

into a lower $N$. acostaensis Zone and an upper $G$. conomiozea Zone appears to be the best that can be achieved with the Leg 94 sites. One improvement which can be made is at Site 608, where the presence of Globorotalia plesiotumida makes possible a subdivision of the $N$. acostaensis Zone on the basis of the FAD of this species. $G$. plesiotumida occurs sporadically at Site 610 and not at all at Site 611, even though both sites are within the geographic range of this species, as delineated by Berggren (1984). Its absence at Site 611 may be due to dissolution, since $G$. plesiotumida is a dissolution-susceptible species; the degree of dissolution is, however, slight, and the absence may have paleoenvironmental causes.

Berggren (1972) first described the species Neogloboquadrina atlantica from North Atlantic specimens, and noted that it changed its coiling direction at, or a little below, what was inferred to be the Miocene/Pliocene boundary. Poore (1979) used this coiling-direction change to indicate the Miocene/Pliocene boundary, noting that this disagreed with the nannofossil age determinations, which suggested that the coiling change took place in the late Miocene. The same discrepancy occurs at Sites 609,610 , and 611 , and the paleomagnetic age determinations (Clement and Robinson, this volume) suggest that the $N$. atlantica coiling change occurs well below the Miocene/Pliocene boundary at all sites. This datum may therefore be of value in subdividing high-latitude upper Miocene sections (Fig. 2).

Coiling-direction changes also occur in the Neogloboquadrina pachyderma group in the uppermost Miocene. Throughout the Pliocene, $N$. pachyderma coils predominantly dextrally. Through the upper Miocene, however, this species changes its coiling direction several times, with a final change to dextral around the Miocene/Pliocene boundary. At Site 607 (the southernmost site at which coring recovered some upper Miocene), samples have predominantly dextral $N$. pachyderma. This may suggest that, as in the Quaternary, coiling-direction changes in $N$. pachyderma are climate-controlled, with sinistral specimens representing cooler conditions. A similar coiling change from sinistral to dextral near the Miocene/ Pliocene boundary has been recorded in the closely related N. acostaensis in the equatorial Pacific (Saito et al., 1975). That coiling change immediately follows a carbon shift, observed throughout the Indo-Pacific, which represents a change in upwelling or circulation patterns.

\section{Pliocene}

Berggren's subdivision of the Pliocene into Zones PL1 to PL6 can be applied at Sites 606 and 607 (37 and $41^{\circ} \mathrm{N}$, 


\begin{tabular}{|c|c|c|c|c|c|c|c|c|c|c|c|c|c|}
\hline $\begin{array}{l}\text { Core-Section } \\
\text { interval (cm) }\end{array}$ & 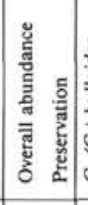 & 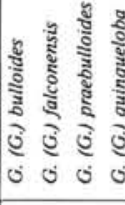 & & 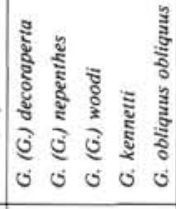 & 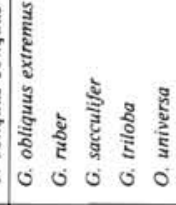 & 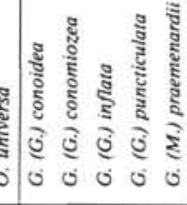 & 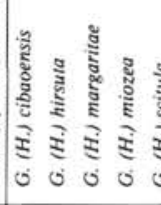 & 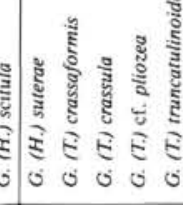 & 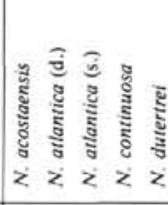 & 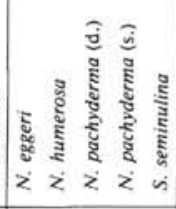 & 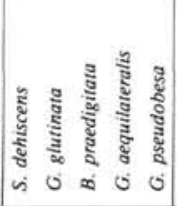 & $\begin{array}{c}\text { Zonation } \\
\text { (Blow, 1969, } \\
\text { Bergeren, 1973) }\end{array}$ & Epoch \\
\hline $\begin{array}{l}1, \mathrm{CC} \\
2, \mathrm{CC} \\
3, \mathrm{CC} \\
4, \mathrm{CC} \\
\text { s,CC } \\
6, \mathrm{CC} \\
7, \mathrm{CC} \\
61 \mathrm{ll}-8 \\
9, \mathrm{CC} \\
10, \mathrm{CC}\end{array}$ & $\mid \begin{array}{lll}A & G \\
A & G \\
A & G \\
A & G \\
A & G \\
A & G \\
A & G \\
A & G \\
R & G & \\
R & G & \end{array}$ & $\begin{array}{ll}\mathrm{C} & \mathrm{C} \\
\mathrm{C} & \mathrm{C} \\
\mathrm{C} & \mathrm{C} \\
\mathrm{C} & \mathrm{C} \\
\mathrm{R} & \mathrm{C} \\
\mathrm{C} & \mathrm{C} \\
\mathrm{C} & \mathrm{C} \\
& \mathrm{F} \\
\mathrm{X} & \mathrm{X}\end{array}$ & $\begin{array}{l}c \\
c \\
c \\
c \\
c\end{array}$ & & $\begin{array}{ll} & \begin{array}{l}\mathrm{R} \\
\mathrm{R}\end{array} \\
\mathrm{R} & \mathrm{R} \\
\mathrm{R} & \mathrm{R} \\
\mathrm{R} & \mathrm{R} \\
& \mathrm{R}\end{array}$ & $\begin{array}{l}F \\
C \\
C \\
C \\
R \\
R \\
F \\
C \\
C \\
C \\
X\end{array}$ & $\begin{array}{ll}R & R \\
R & R \\
R & R \\
R & R \\
& R \\
& R \\
& R \\
\text { No core } & R \\
r & \\
& R \\
\end{array}$ & $\begin{array}{ll}\mathrm{R} & \mathrm{F} \\
& \mathrm{R} \\
\mathrm{C} & \mathrm{R} \\
\mathrm{R} & \\
\mathrm{C} & \mathrm{R}\end{array}$ & $\begin{array}{l}R \\
R \\
R \\
R \\
R \\
R \\
R \\
R\end{array}$ & 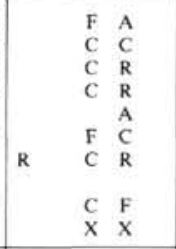 & $\begin{array}{ll}R & \\
R & R \\
C & R \\
C & \\
C & \\
C & R \\
C & R\end{array}$ & N22 & Pleistocene \\
\hline 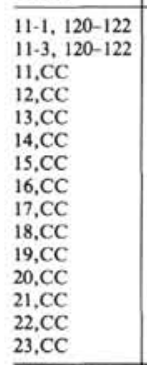 & $\mid$\begin{tabular}{ll|l}
$A$ & $G$ \\
$A$ & $G$ \\
$A$ & $G$ \\
$C$ & $G$ \\
$A$ & $G$ \\
$A$ & $G$ \\
$A$ & $M$ \\
$A$ & $M$ \\
$A$ & $M$ \\
$A$ & $M$ \\
$A$ & $M$ \\
$A$ & $G$ \\
$A$ & $G$ \\
$A$ & $G$ \\
$A$ & $G$ & \\
$A$ & $G$ &
\end{tabular} & $\begin{array}{ll}\text { C } & \\
C & \\
C & R \\
C & R \\
C & \\
C & R \\
R & R \\
R & R \\
F & R \\
R & R \\
C & \\
C & \\
C & \\
C & \\
C & \\
\end{array}$ & $\begin{array}{l}R \\
R \\
R \\
R \\
R \\
R \\
R \\
R\end{array}$ & $\begin{array}{l}R \\
R \\
R\end{array}$ & $\begin{array}{ll}\mathrm{R} & \mathrm{R} \\
& \mathrm{F} \\
& \mathrm{R} \\
& \mathrm{R} \\
\mathrm{R} & \mathrm{R} \\
\mathrm{R} & \mathrm{R} \\
& \mathrm{R} \\
& \mathrm{R} \\
\mathrm{R} & \mathrm{R} \\
\mathrm{R} & \mathrm{C} \\
& \mathrm{C} \\
\mathrm{R}\end{array}$ & $\begin{array}{ll}\text { F } \\
\text { C } \\
C \\
\text { R } \\
\text { Cf. } R \\
\text { C. } \\
\text { R } \\
\text { F } \\
\text { F } \\
\text { C } \\
C \\
C \\
C \\
C \\
C \\
C\end{array}$ & $\begin{array}{ll}R & \\
R & \\
F & \\
R & \\
R & \\
R & \\
R & \\
R & \\
R & \\
R & \\
R & \\
R & \\
R & \\
H & \\
R & \end{array}$ & 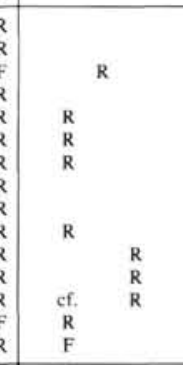 & $\begin{array}{ll}\mathrm{R} & \mathrm{C} \\
\mathrm{R} & \mathrm{A} \\
\mathrm{R} & \mathrm{C} \\
\mathrm{R} & \mathrm{A} \\
\mathrm{R} & \mathrm{C} \\
& \mathrm{C} \\
& \mathrm{C} \\
& \mathrm{C} \\
& \mathrm{C} \\
& \mathrm{C} \\
& \mathrm{C}\end{array}$ & 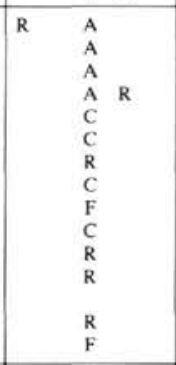 & $\begin{array}{ll}R & \\
R & \\
R & \\
R & \\
F & R \\
F & R \\
R & R \\
R & R \\
R & \\
R & \\
R & \\
R & \\
R & \\
R & \\
R\end{array}$ & $\begin{array}{l}\mathrm{PL} \\
3-6\end{array}$ & $\begin{array}{l}\text { late } \\
\text { Pliocene }\end{array}$ \\
\hline 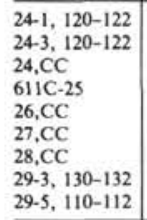 & $\mid$\begin{tabular}{ll|}
$A$ & $G$ \\
$A$ & $G$ \\
$A$ & $G$ \\
$A$ & $G$ \\
$A$ & $G$ \\
$A$ & $G$ \\
$A$ & $G$ \\
$A$ & $G$
\end{tabular} & $\begin{array}{l}\text { c } \\
\text { c } \\
\text { c } \\
\text { c } \\
\text { c } \\
\text { c } \\
\text { c } \\
\text { C }\end{array}$ & $\begin{array}{l}\mathrm{R} \\
\mathrm{R}\end{array}$ & \begin{tabular}{|lll} 
& $\mathrm{R}$ & \\
$\mathrm{R}$ & $\mathrm{R}$ & $\mathrm{R}$ \\
$\mathrm{R}$ & $\mathrm{R}$ & $\mathrm{R}$ \\
$\mathrm{R}$ & & \\
& & $\mathrm{R}$
\end{tabular} & 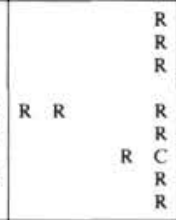 & $\begin{array}{l}\mathrm{R} \\
\mathrm{F} \\
\mathrm{C}\end{array}$ & $\begin{array}{cc}R & R \\
R & R \\
R & R \\
\text { No core } & F \\
R & R \\
R & F \\
R & R \\
R & R \\
R & R\end{array}$ & $\begin{array}{l}F \\
R \\
R\end{array}$ & \begin{tabular}{|ll} 
& C \\
& C \\
cf. & C \\
F & C \\
F & C \\
C & C \\
& C \\
& C
\end{tabular} & $\begin{array}{ll}\mathrm{F} \\
\mathrm{C} \\
\mathrm{C} \\
\mathrm{C} \\
\mathrm{C} \\
\mathrm{C} \\
\mathrm{C} \\
\mathrm{C} \\
\mathrm{F} & \mathrm{A}\end{array}$ & $\begin{array}{l}R \\
R \\
R \\
R \\
R \\
R \\
F \\
R \\
R\end{array}$ & PL2 & $\begin{array}{l}\text { early } \\
\text { Pliocene }\end{array}$ \\
\hline \begin{tabular}{l|l}
$29, \mathrm{CC}$ \\
$30 . \mathrm{CC}$ \\
\end{tabular} & $\begin{array}{|ll|}A & G \\
A & G \\
\end{array}$ & $\begin{array}{l}\mathrm{R} \\
\mathrm{C} \\
\end{array}$ & ${ }^{R}$ & $\begin{array}{lllll}R & R & R & R \\
& \text { cf. } & & R & R \\
\end{array}$ & $\begin{array}{ll} & R \\
R & R \\
\end{array}$ & & $\begin{array}{ll}F & R \\
R & F \\
\end{array}$ & & $\begin{array}{|ll|}\mathrm{C} & \mathrm{C} \\
\mathrm{F} & \mathrm{R} \\
\end{array}$ & $\begin{array}{ll}\mathrm{C} \\
\mathrm{R} & \mathrm{C} \\
\end{array}$ & $\begin{array}{|lll|}R & & \\
R & & \\
\end{array}$ & PLI & \\
\hline 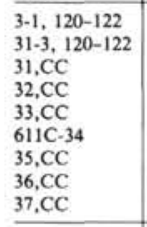 & $\mid$\begin{tabular}{ll|}
$A$ & $G$ \\
$A$ & $G$ \\
$A$ & $G$ \\
$C$ & $M$ \\
$A$ & $G$ \\
$A$ & $G$ \\
$A$ & $G$ \\
$A$ & $G$ \\
$A$ &
\end{tabular} & 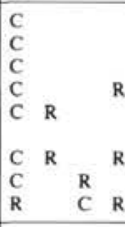 & & $\begin{array}{rrrr} & & R & R \\
R & R & \\
R & R & & R \\
& R & & \\
& R & & \\
& R & & \\
\end{array}$ & ${ }^{R}$ & er. & 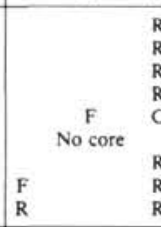 & & $\begin{array}{llll} & & C & R \\
& & C & \\
F & R & C & \\
R & & C & R \\
F & C & C & F \\
F & & C & F \\
F & & C & C \\
C & & C & C \\
\end{array}$ & $\begin{array}{llll}\mathrm{R} & \mathrm{C} & \\
& & \\
& \mathrm{C} & \\
\mathrm{C} & \mathrm{C} \\
& \mathrm{C} & \\
& & \\
& & \mathrm{C} \\
& & \mathrm{C} \\
& \mathrm{C} & \mathrm{C} \\
\end{array}$ & $\begin{array}{lll}R & & R \\
R & \\
R & \\
R & \\
\text { C } & \\
F & \\
\text { R } & \\
\end{array}$ & ? & $\begin{array}{c}\begin{array}{c}\text { late } \\
\text { Miocene }\end{array} \\
\text {. }\end{array}$ \\
\hline $\begin{array}{l}38, \mathrm{CC} \\
39, \mathrm{CC} \\
40, \mathrm{CC}\end{array}$ & $\mid \begin{array}{ll}A & G \\
A & M \\
C & M\end{array}$ & \begin{tabular}{|ll}
$R$ & $C$ \\
$F$ & \\
\end{tabular} & & $\begin{array}{lll} & R \\
& R & R \\
\end{array}$ & R & 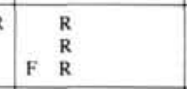 & R & & $\begin{array}{lll}\mathrm{C} & \mathrm{C} & \mathrm{F} \\
\mathrm{R} & \mathrm{F} \\
& \mathrm{C} & \mathrm{R} \\
\end{array}$ & 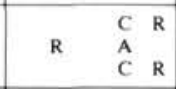 & $\begin{array}{l}\mathrm{R} \\
\mathrm{R} \\
\mathrm{R}\end{array}$ & $\begin{array}{c}G . \\
\text { cono- } \\
\text { mio. }\end{array}$ & \\
\hline $\begin{array}{l}41, \mathrm{CC} \\
42, \mathrm{CC} \\
43, \mathrm{CC} \\
44, \mathrm{CC} \\
45, \mathrm{CC} \\
46, \mathrm{CC} \\
47, \mathrm{CC}\end{array}$ & $\begin{array}{|ll|}R & M \\
F & M \\
A & G \\
A & G \\
A & G \\
C & M \\
C & M\end{array}$ & 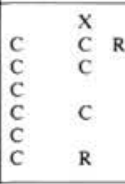 & & 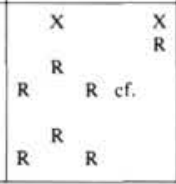 & \begin{tabular}{|cccc} 
& & & $X$ \\
& & $R$ \\
& & $R$ \\
& & $R$ \\
cf. & & $C$ \\
& & $R$ \\
& & $R$ & $R$ \\
& & $R$ \\
\end{tabular} & $\begin{array}{l}\text { cf. } \\
\text { cf. } \\
\text { cf. }\end{array}$ & $\begin{array}{lll} & R \\
& R \\
R & R \\
\text { cf. } & F \\
F & R \\
F & R\end{array}$ & & \begin{tabular}{|lllll} 
& & & & $X$ \\
$C$ & $R$ & $C$ & $C$ \\
$R$ & $C$ & $C$ & $C$ \\
$R$ & $R$ \\
$C$ & $R$ & $C$ \\
$C$ & $F$ & $C$ \\
$R$ & & & $C$ \\
$R$ & & $C$ \\
\end{tabular} & $\begin{array}{llll} & & X & X \\
& R & C & R \\
& & C & \\
& C & R \\
& C & & R \\
& C & & R \\
R & C & & R \\
\end{array}$ & 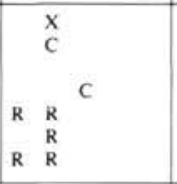 & N. acostaensis & \\
\hline
\end{tabular}

Nom fauna too poorly preserved for an estimate. 
Table 15. Distribution of planktonic foraminifers, Holes 611D and 61IE.

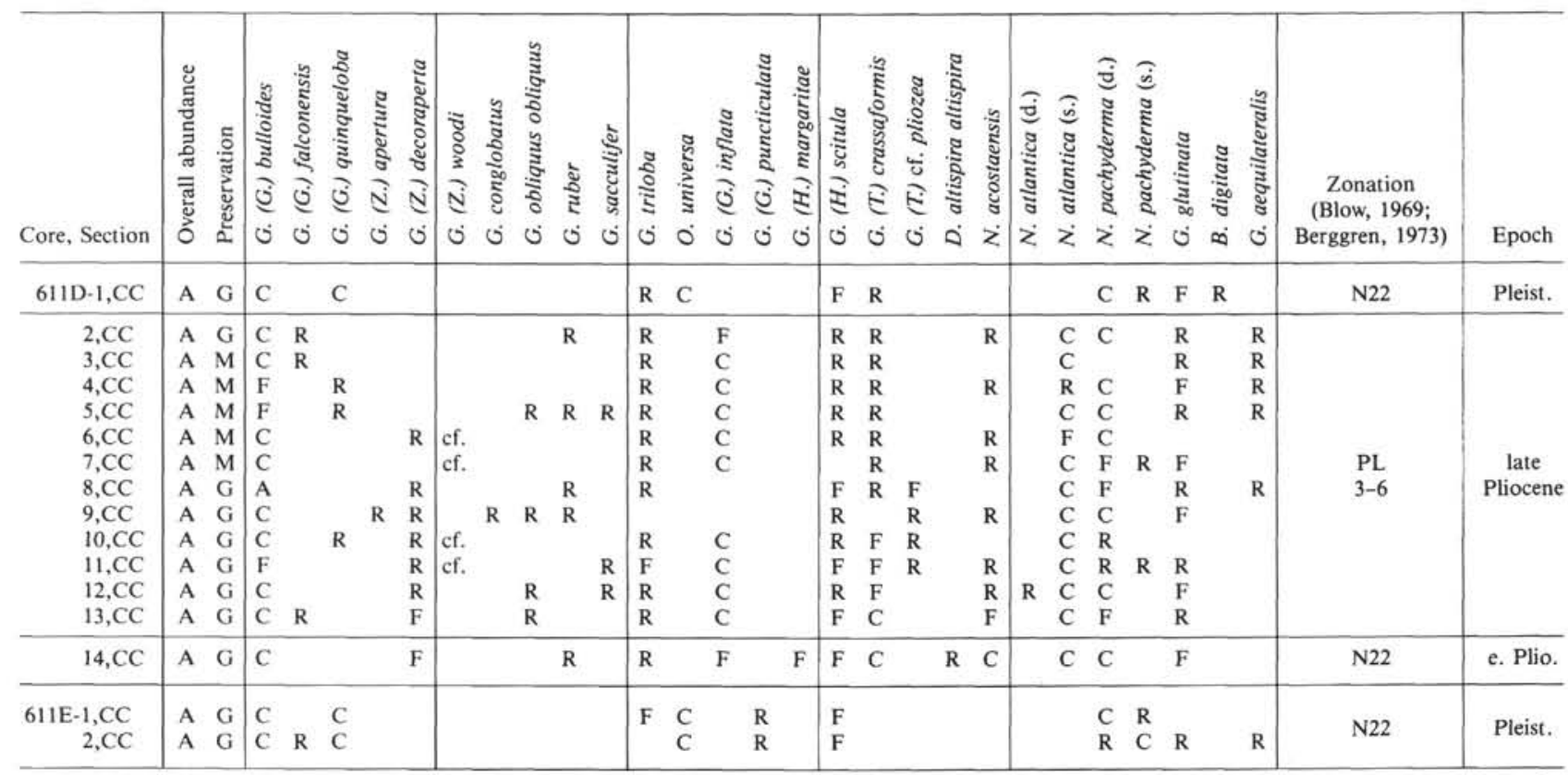

Note: Overall abundance: $\mathrm{A}=$ abundant. Preservation: $\mathrm{G}=$ good; $\mathrm{M}=$ moderate. Species abundance: $\mathrm{C}=$ common $(15-30 \%) ; \mathrm{F}=\mathrm{few}(3-15 \%) ; \mathrm{R}=$ rare $(<3 \%)$.

respectively), where all zones can be recognized. North of this, however, there is a progressive loss of species, so that the following zones cannot be differentiated: at Site 608, Zones PL4 to PL6; at Site 609, Zones PL3 to PL6; and at Sites 610 and 611, Zones PL1, PL2, and PL3 to PL6. There is therefore, a need for a high-latitude zonation of the North Atlantic Pliocene that takes over from the PL zonation north of about $45^{\circ} \mathrm{N}$. Berggren (1972) divided the Pliocene of this region into three zones, a lower Globorotalia puncticulata Zone followed by the Globorotalia crassaformis Zone and the $G$. inflata Zone at the top (Fig. 2). Later, Poore (1979) placed all of the upper Pliocene in the $G$. inflata Zone, with the upper part of the lower Pliocene in the G. puncticulata Zone and the lower part, together with the whole of the upper Miocene, in the $N$. acostaensis Zone. Poore also suggested that the Pliocene equated with the total range of sinistrally coiled $N$. atlantica (Fig. 2).

The stratigraphic ranges of the foregoing species at the Leg 94 sites show that some revision of the published zonations is required. $G$. puncticulata has its first occurrence above the Miocene/Pliocene boundary, as described by Poore (1979). This datum can be found at all the Leg 94 sites, and appears to be a useful marker, even though its evolution from Globorotalia sphericomiozea cannot be followed in the North Atlantic. At all Leg 94 sites $G$. puncticulata and G. crassaformis first appeared at the same time, so a distinction between the G. puncticulata and $G$. crassaformis zones cannot be made. This appears to be because $G$. crassaformis preferred warmer water than G. puncticulata. G. crassaformis is relatively rare at the northern Sites 610 and 611 , and may have had a restricted range in sites farther north, such as Site $116\left(57^{\circ} \mathrm{N}, 53^{\circ} \mathrm{W}\right)$, which were used by Poore and Berggren (1975) to create their zonation.

Poore and Berggren (1975) regarded the G. inflata Zone as being uppermost Pliocene, whereas Poore (1979) placed all of the upper Pliocene in this zone. Poore did, however, record the first occurrence of ice-rafted material, and the first occurrence of $G$. inflata correlates closely with this level in his cores. The onset of ice-rafting began about 2.4 Ma in the North Atlantic (Shackleton et al., 1984), considerably later than the $3.4 \mathrm{Ma}$ age of the lower/upper Pliocene boundary, as estimated by Berggren et al. (in press). $G$. inflata first appeared a little later than the onset of ice-rafting at the Leg 94 sites, but it provides a useful datum which can be identified in all holes. Malmgren and Kennett $(1981,1982)$ showed that G. inflata evolved from G. puncticulata at around 2.9 $\mathrm{Ma}$ in the South Pacific. This is somewhat earlier than in the North Atlantic, where G. puncticulata became extinct and $G$. inflata first appeared between 2 and $2.4 \mathrm{Ma}$ (Weaver and Clement, this volume). At every site there is a short interval with neither species between the LAD of $G$. puncticulata and the FAD of $G$. inflata. It is therefore possible that the first occurrence of $G$. inflata in the North Atlantic represents a migrational event, even though some specimens intermediate between the two species can be found in the uppermost Pliocene (Zones PL5 and PL6). The LAD of $G$. puncticulata is coincident with, or slightly older than, the LAD of $N$. atlantica (s) at Sites 609 to 611 , but farther south $N$. atlantica occurs too rarely to be useful. Poore (1979) recorded similar relationship between the LADs of these two species in Hole $410\left(45^{\circ} \mathrm{N}\right)$, although he recorded a somewhat earlier LAD of $G$. puncticulata at the more northerly Sites 407 
and 408 (each at $63^{\circ} \mathrm{N}$ ). Thus, the LAD of $N$. atlantica may be a more reliable stratigraphic marker than the LAD of G. puncticulata in the extreme North Atlantic.

\section{Quaternary}

The Quaternary/Pliocene boundary, as currently defined at 1.6 Ma (Berggren et al., 1980; Berggren et al., in press), cannot be identified on the basis of planktonic foraminifers. Globorotalia truncatulinoides has an FAD at $\sim 1.9 \mathrm{Ma}$ in subtropical and mid-latitude cores (Berggren et al., 1980), but this FAD has been shown to become progressively younger toward the Antarctic (Kennett, 1970b). In the North Atlantic the same pattern emerges; rare G. truncatulinoides at Sites 610 and 611 first appears well into the Quaternary (Weaver and Clement, this volume; Huddlestun, 1985). The FAD of $G$. truncatulinoides provides a reliable datum only as far north as about $50^{\circ} \mathrm{N}$. Evidence of the evolution of $G$. truncatulinoides from Globorotalia tosaensis is limited to Site $606 ; G$. tosaensis is in fact very rare at all the sites studied, and cannot be used as a stratigraphic marker.

Huddlestun (1985) suggests that the first occurrence of sinistrally coiled $N$. pachyderma (encrusted type) is a useful marker in the high-latitude North Atlantic. Large numbers of the form first appear close to the top of the Pliocene (Poore and Berggren, 1975, fig. 4). Below this a few sinistrally coiled $N$. pachyderma can be found, and these are generally of the non-encrusted type. At all sites studied, including Site 116 of Poore and Berggren (1975), there is a distinctive interval above the LAD of $N$. atlantica before the FAD of the encrusted $N$. pachyderma. This was recorded as division $\mathrm{B}_{2}$ by Poore and Berggren (1975). The interval contains glacial detritus, and it is not clear why the cold-water species $N$. atlantica and $N$. pachyderma (s) are absent. Encrusted N. pachyderma (s) is restricted to cool conditions, and it is most useful as a stratigraphic marker in high latitudes, probably north of about $45^{\circ} \mathrm{N}$. At Sites 606 and 607 it has its FAD near that of $G$. truncatulinoides, but its occurrence at these latitudes is too sporadic for it to be a reliable marker.

Pujol and Duprat (1983) produced for Sites 515 to 518 (Rio Grande Rise) a detailed Quaternary stratigraphy in which five biozones were created. The coarse sampling interval employed in this study has precluded such a detailed analysis, but some observations may be relevant. Globorotalia crassula s.l. has been found higher in the Quaternary than suggested by Pujol and Duprat; thus, biozone E has not been recognized. Neogloboquadrina eggeri occurs commonly around the Pliocene/Quaternary boundary at Sites 606 to 609 , and may provide a useful marker, comparable to the top of biozone D. A distinction between biozones $\mathrm{C}$ and $\mathrm{B}$ cannot be made, but a distinct biozone A, based on the presence of Globorotalia hirsuta, can be identified at all sites. This latter interval, from the FAD of $G$. hirsuta to the Recent, may provide the most useful method of subdividing the Quaternary in the mid- to high-latitude North Atlantic. According to Pujol and Duprat (1985), G. hirsuta first appeared in late oxygen-isotope stage 12 .

\section{CONCLUSION}

The most useful zonation for the southern sites, as far north as about $42^{\circ} \mathrm{N}$, is the PL zonation of Berggren (1973). North of about $45^{\circ} \mathrm{N}$, the informal zonation outlined in Figure 2 can be applied at least as far north as $55^{\circ} \mathrm{N}$ and probably as far north as $65^{\circ} \mathrm{N}$. A fuller discussion of this zonation and a comparison between it and the paleomagnetic record is presented in another chapter (Weaver and Clement, this volume). For comparison, previous North Atlantic high-latitude zonations are reproduced in Figure 2, but it must be borne in mind that the cored sections on which these were based were generally incomplete. Further, paleomagnetic calibration was poor or absent at these sites.

\section{TAXONOMIC NOTES}

The taxonomy used here is based largely on the atlas of Kennett and Srinivasan (1983). A few omissions from this atlas are also discussed here.

Beella digitata (Brady, 1879)

Beella praedigitata (Parker, 1967)

Dentoglobigerina altispira altispira Cushman and Jarvis, 1936), Pl. 2,

Fig. 5. Specimens of this species rarely show the very high trochospire recorded for specimens from tropical sites. Dentoglobigerina altispira globosa Bolli, 1957

Globigerina (Globigerina) angustiumbilicata Bolli, 1957

Globigerina (Globigerina) bulloides d'Orbigny, 1826

Globigerina (Globigerina) falconensis Blow, 1959

Globigerina (Globigerina) praebulloides Blow, 1959

Gloigerina (Globigerina) quinqueloba Natland, 1938

Globigerina (Globigerina) umbilicata Orr and Zaitseff, 1971

Globigerina (Zeaglobigerina) apertura Cushman, 1918

Globigerina (Zeaglobigerina) decoraperta Takayanagi and Saito, 1962

Globigerina (Zeaglobigerina) nepenthes Todd, 1957, Pl. 2, Fig. 9

Globigerina (Zeaglobigerina) rubescens Hofker, 1956

Globigerina (Zeaglobigerina) woodi Jenkins, 1960

Globigerina aequilateralis (Brady, 1879)

Globigerinella calida (Parker, 1962)

Globigerinella obesa (Bolli, 1957)

Globigerinella pseudobesa (Salvatorini, 1966)

Globigerinita glutinata (Egger, 1893). No distinction has been made between this species and G. uvula (Ehrenberg, 1861)

Globigerinoides conglobatus (Brady, 1879)

Globigerinoides kennetti Keller and Poore, 1980

Globigerinoides obliquus obliquus Bolli, 1957

Globigerinoides obliquus extremus Bolli and Bermudez, 1965, Pl. 2, Fig. 3.

Globigerinoides ruber (d'Orbigny, 1839)

Globigerinoides sacculifer (Brady, 1877)

Globigerinoides tenellus Parker, 1958

Globigerinoides triloba (Reuss, 1850)

Globoquadrina dehiscens (Chapman, Parr, and Collins, 1934)

Globorotalia (Globoconella) conoidea Walters, 1965, Pl. 3, Figs. 1-2. This species is rarely common. In some samples specimens are very heavily encrusted.

Globorotalia (Globoconella) conomiozea Kennett, 1966, P1. 2, Figs. $10-12$. This species shows considerable variability in the degree of vaulting of the umbilical side. Some specimens are more like $G$. conoidea in apertural view, but can be distinguished by having a maximum of $41 / 4$ chambers in the final whorl.

Globorotalia (Globoconella) inflata (d'Orbigny, 1839), Pl. 3, Figs. 67. Three- and four-chambered specimens of this species are common. The four-chambered forms can be distinguished from G. puncticulata because they have a larger aperture, a broadly-rounded periphery, and more inflated chambers.

Globorotalia (Globoconella) miozea Finlay, 1939

Globorotalia (Globoconella) puncticulata (Deshayes, 1832), Pl. 3, Figs. 8-9.

Globorotalia (Globorotalia) merotumida Blow and Banner, 1965 
Globorotalia (Globorotalia) plesiotumida Blow and Banner, 1965, Pl. 3, Figs. 3-5

Globorotalia (Globorotalia) tumida (Brady, 1877)

Globorotalia (Hirsutella) cibaoensis Bermudez, 1949, Pl. 2, Figs. 1315. Specimens of this species are not typical, but are somewhat more angular than usual. The biconvex nature of the test, however, suggests closer affinities to this species than to G. scitula.

Globorotalia (Hirsutella) hirsuta (d'Orbigny, 1839), Pl. 2, Fig. 2

Globorotalia (Hirsutella) juanai Bermudez and Bolli, 1969

Globorotalia (Hirsutella) margaritae Bolli and Bermudez, 1965. The oldest specimens of this species are more akin to G. margaritae primitiva (Cita, 1973), in that they have a plano-convex to biconvex axial profile and a less obvious keel. All intermediate stages can be found, however, and a distinction is not made.

Globorotalia (Hirsutella) scitula (Brady, 1882)

Globorotalia (Hirsutella) suterae Catalano and Sprovieri, 1971

Globorotalia (Menardella) limbata (Fornasini, 1902)

Globorotalia (Menardella) menardii (Parker, Jones, and Brady, 1865)

Globorotalia (Menardella) miocenica Palmer, 1945, Pl. 2, Fig. 4

Globorotalia (Menardella) praemenardii Cushman and Stainforth, 1945

Globorotalia (Truncorotalia) crassaformis Galloway and Wissler, 1927, Pl. 3, Figs. 10-11. No subdivision of this species into subspecies or varieties has been made, and it therefore covers a range of forms from keeled to nonkeeled and from vaulted to compact.

Globorotalia (Truncorotalia) crassula Cushman and Stewart, 1930

Globorotalia (Truncorotalia) cf. crassula Cushman and Stewart, 1930, Pl. 3, Figs. 12-15. This species is variable in appearance and is sometimes very encrusted. A weak keel is visible in less-encrusted specimens, and the ventral sutures are slightly recurved. This species may previously have been recorded as $G$. crassula, from which it differs by being less conical and having more embracing chambers and a more rectangular outline.

Globorotalia (Truncorotalia) tosaensis Takayanagi and Saito, 1962

Globorotalia (Truncorotalia) truncatulinoides (d'Orbigny, 1839), Pl. 2, Fig. 1

Hastigerina pelagica (d'Orbigny, 1839)

Neogloboquadrina acostaensis (Blow, 1959), Pl. 1, Figs. 5-6

Neogloboquadrina atlantica (Berggren, 1972), Pl. 1, Figs. 13-15

Neogloboquadrina continuosa (Blow, 1959), Pl. 1, Figs. 7-9. According to Kennett and Srinivasan (1983), this species becomes extinct near the base of the upper Miocene. In this study numerous specimens have been found, however-from the upper Miocene and lower Pliocene-which are very close to this species. They have higharched, comma-shaped apertures. A similar distribution, also in the North Atlantic, was recoded by Poore (1979).

Neogloboquadrina dutertrei (d'Orbigny, 1839)

Neogloboquadrina eggeri (Rhumbler, 1901) Pl. 1, Figs. 10-12. This species is very similar to $N$. dutertrei but lacks umbilical teeth. It has 4 to 5 chambers in the final whorl and is nearly always dextrally coiled.

Neogloboquadrina humerosa (Takayanagi and Saito, 1962)

Neogloboquadrina pachyderma (Ehrenberg, 1861), Pl. 1, Figs. 1-4. Left- and right-coiled forms of this species are of importance in paleoenvironmental reconstructions. At least two distinct forms of the left-coiled variety exist, however; the Pleistocene form is highly encrusted, and the older left-coiled forms are identical to the rightcoiled form in all respects except coiling.

Orbulina universa d'Orbigny, 1839

Pulleniatina obliquiloculata (Parker and Jones, 1865)

Pulleniatina praecursor Banner and Blow, 1967

Sphaeroidinella dehiscens (Parker and Jones, 1865)

Sphaeroidinellopsis seminulina (Schwager, 1866), Pl. 2, Fig. 6

Turborotalita humilis (Brady, 1884)

Turborotalita pseudopumilio (Bronnimann and Resig, 1971)

\section{ACKNOWLEDGMENTS}

I thank Graham Jenkins (Open University) for his encouragement and assistance throughout this study. Drs. W. A. Berggren, C. Pujol, and D. G. Masson offered helpful comment on the manuscript. Miss E. Woodward and Mr. G. S. Morey drafted the diagrams, and Mr. G. Rothwell and Mr. M. Smithers took the SEM pictures.

\section{REFERENCES}

Berger, W. H., 1970. Foraminiferal ooze: Solution at depths. Science, $156: 383-385$

Berggren, W. A., 1972. Cenozoic biostratigraphy and paleobiogeography of the North Atlantic. In Laughton, A. S., Berggren, W. A., et al., Init. Repts. DSDP, 12: Washington (U.S. Govt. Printing Office), 965-1001.

1973. The Pliocene time scale: Calibration of planktonic foraminiferal and calcareous nannoplankton zones. Nature, 243: 391-397.

, 1977. Late Neogene planktonic foraminiferal biostratigraphy of the Rio Grande Rise (South Atlantic). Mar. Micropaleontol., 2:251-265.

1984. Correlation of Atlantic, Mediterranean, and IndoPacific Neogene stratigraphies: Geochronology and chronostratigraphy. Proc. Int. Geol. Correlation Prog. (Vol. 114): Int. Workshop Pacific Neogene Biostrat., 29-60

Berggren, W. A., Aubrey, M. P., and Hamilton, N., 1983. Neogene magnetobiostratigraphy of Deep Sea Drilling Project Site 516 (Rio Grande Rise, South Atlantic). In Barker, P. F., Carson, R. L., Johnson, D. A., et al., Init. Repts. DSDP, 72: Washington (U.S. Govt. Printing Office), 675-713.

Berggren, W. A., Burckle, L. H., Cita, M. B., Cooke, H. B. S., Funnell, B. M., et al., 1980. Towards a Quaternary time scale. Quat. Res., 13:277-302.

Berggren, W. A., Kent, D. V., and Van Couvering, J. A., in press. Neogene geochronology and chronostratigraphy. In Snelling, N. J. (Ed.), Geochronology and the Geological Record. Geol. Soc. London Spec. Publ.

Blow, W. H., 1969. Late middle Eocene to Recent planktonic foraminiferal biostratigraphy. In Brönniman, P., and Renz, H. H. (Eds.), Proc. First Int. Plankt. Conf., 1:199-421.

Bolli, H. M., and Saunders, J., in press. Plankton stratigraphy: Cambridge, U.K. (Univ. Press).

Huddlestun, P. F., 1985. Planktonic foraminiferal biostratigraphy, Deep Sea Drilling Project Leg 81. In Roberts, D. G., Schnitker, D., et al., Init. Repts. DSDP, 81: Washington (U.S. Govt. Printing Office), 429-438.

Kennett, J. P., 1970a. Comparison of Globigerina pachyderma (Ehrenberg) in Arctic and Antarctic areas. Cushman Found. Foram. Res. Contr., 21 (Pt. 2):47-49.

$1970 \mathrm{~b}$. Pleistocene paleoclimates and foraminiferal biostratigraphy in subantarctic deep-sea cores. Deep-Sea Res., 17:125-140.

1973. Middle and late Cenozoic planktonic foraminiferal biostratigraphy of the Southwest Pacific, DSDP Leg 21. In Burns, R. E., Andrews, J. E., et al., Init. Repts. DSDP, 21: Washington (U.S. Govt. Printing Office), 575-639.

Kennett, J. P., and Srinivasan, M. S., 1975. Stratigraphic occurrences of the Miocene planktonic foraminifera Globoquadrina dehiscens in early Pliocene sediments of the Indian Ocean. Rev. Española Micropaleontol., 7:5-14.

1983. Neogene Planktonic Foraminifera: Stroudsburg, Pennsylvania (Hutchinson Ross).

Malmgren, B. A., and Kennett, J. P., 1981. Phyletic gradualism in a late Cenozoic planktonic foraminiferal lineage, DSDP Site 284, southwest Pacific. Palaeobiology, 7:230-240.

1982. The potential of morphometrically based phylo-zonation: Application of a late Cenozoic planktonic foraminiferal lineage. Mar. Micropalentol., 7:285-296.

Poore, R. Z., 1979. Oligocene through Quaternary planktonic foraminiferal biostratigraphy of the North Atlantic: DSDP Leg 49. In Luyendyk, B. P., Cann, J. R., et al., Init. Repts. DSDP, 49: Washington (U.S. Govt. Printing Office), 447-517.

Poore R. Z., and Berggren, W. A., 1975. Late Cenozoic planktonic foraminiferal biostratigraphy and paleoclimatology of Hatton-Rockall Basin: DSDP Site 116. J. Foram. Res., 5:270-293.

Pujol, C., 1983. Cenozoic planktonic foraminiferal biostratigraphy of the southwestern Atlantic (Rio Grande Rise): DSDP Leg 72. In Barker, P. F., Carlson, R. L., Johnson, D. A., et al., Init. Repts. DSDP, 72: Washington (U.S. Govt. Printing Office), 623-673.

Pujol, C., and Duprat, J., 1983. Quaternary planktonic foraminifers of the southwestern Atlantic (Rio Grande Rise), Deep Sea Drilling 


\section{P. P. E. WEAVER}

Project Leg 72. In Barker, P. F., Carlson, R. L., Johnson, D. A., et al., Init. Repts. DSDP, 72: Washington (U.S. Govt. Printing Office), 601-622.

1985. Quaternary and Pliocene planktonic foraminifers of the northeastern Atlantic (Goban Spur), DSDP Leg 80. In Graciansky, P. C. de, Poag, C. W., et al., Init. Repts. DSDP, 80: Washington (U.S. Govt. Printing Office), 683-723.

Ruddiman, W. F., and McIntyre, A., 1976. Northeast Atlantic paleoclimatic changes over the past 600,000 years. In Cline, R. M., and Hays, J. D. (Eds.), Investigation of Late Quaternary Paleoceanography and Paleoclimatology. Mem. Geol. Soc. Am., 145:111-146.

Saito, T., Buckle, L. H., and Hays, J. D., 1975. Late Miocene to Pleistocene biostratigraphy of equatorial Pacific sediments. In Saito, T. and Buckle, L. (Eds.), Late Neogene Epoch Boundaries: New York (Micropaleontol. Press), pp. 226-244.
Shackleton, N. J., Backman, J., Zimmerman, H., Kent, D. V., Hall, M. A., et al., 1984. Oxygen isotope calibration of the onset of icerafting and history of glaciation in the North Atlantic region. $\mathrm{Na}$ ture, 307:620-623.

Stainforth, R. M., Lamb, J. L., Luterbacher, H., Beard, J. H., and Jeffords, R. M., 1975. Cenozoic planktonic foraminiferal zonation and characteristics of index forms. Univ. Kans. Paleontol. Contrib., Article 62.

Weaver, P. P. E., 1983. An integrated stratigraphy of the upper Quaternary of the King's Trough flank area, N.E. Atlantic. Oceanol. Acta, 6:451-456.

Date of Initial Receipt: 18 December 1984 Date of Acceptance: 25 July 1985 


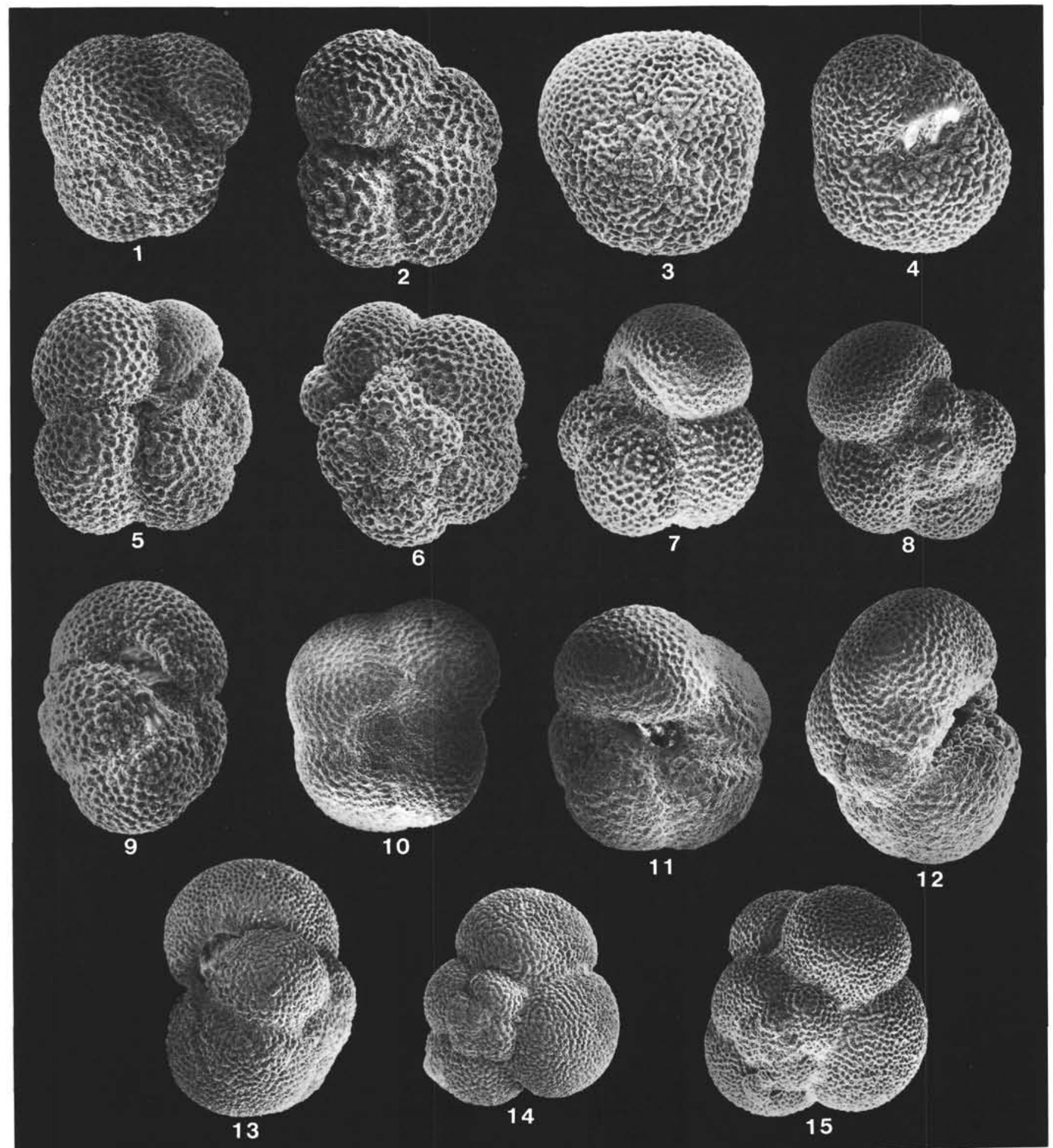

Plate 1. Neogloboquadrina spp. 1-2. N. pachyderma Ehrenberg, dextral form, Sample 611D-2,CC, $\times 170$. 3-4. N. pachyderma Ehrenberg, sinistral form, Sample 610-5,CC $\times 150$; note heavy encrustation which almost obliterates chamber form. 5-6. N. acostaensis (Blow, 1959), Sample 608-15,CC, $\times 150$. 7-9. N. continuosa (Blow, 1959), Sample 610-15,CC, (7-8) $\times 120,(9) \times 150$. 10-12. N. eggeri $($ Rhumbler), Sample 607A-7,CC, $\times 80$. 13-15. N. atlantica (Berggren), sinistral type, Sample 611D-2,CC $\times 80$. 


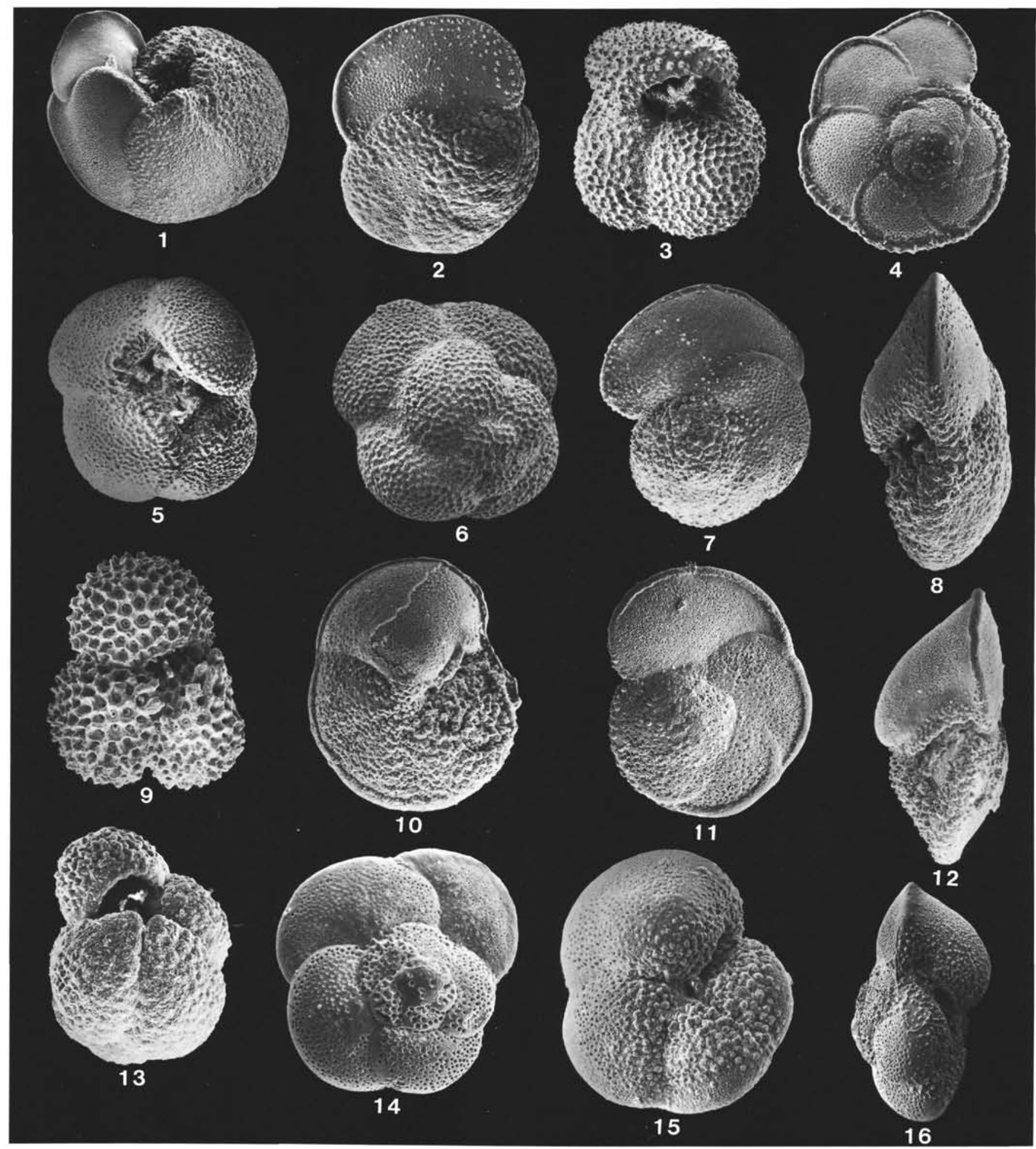

Plate 2. 1-2. Sample 606-1,CC (1) Globorotalia (Truncorotalia) truncatulinoides (d'Orbigny), $\times 50$. (2) Globorotalia (Hirsutella) hirsuta (d'Orbigny), $\times 55$ 3, 9. Sample 606-13,CC, (3) Globigerinoides obliquus extremus (Bolli and Bermudez), $\times 110$, (9) Sphaeroidinellopsis seminulina (Schwager), $\times 85$. 4. Globorotalia (Menardella) miocenica (Palmer), Sample 606-12-3, 120-122 cm, $\times 75$. 5-6. Dentoglobigerina altispira (Cushman and Jarvis), Sample 607-15-1, 118-120 cm, $\times 70$. 7. Globorotalia (Hirsutella) margaritae (Bolli and Bermudez, Sample 607-22-5, $120-122, \times 100$. 8. Globorotalia (H.) cf. margaritae, early form with biconvex outline, Sample 607A-21,CC, $\times 115$. 10-16. Sample 60815,CC (10-12) Globorotalia (Globoconella) conomiozea, Kennett, $\times 110,(13)$ Globigerina (Zeaglobigerina) nepenthes, $\times 120,(14-16)$ Globorotalia (Hirsutella) cibaoensis (Bermudez), $(4, \times 130 ; 16, \times 100)$. 


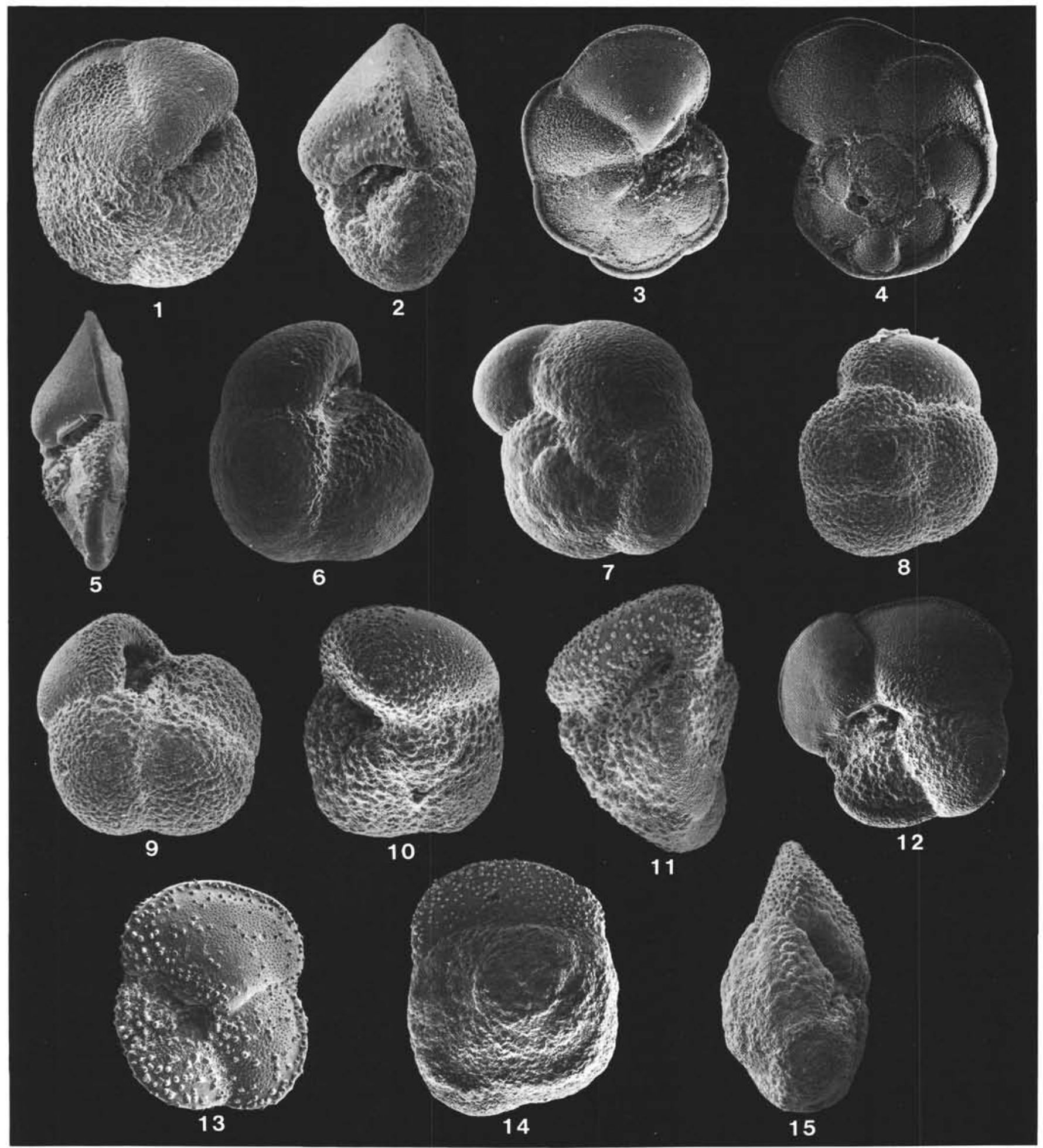

Plate 3. 1-5. Sample 608-19,CC (1-2) Globorotalia (Globoconella) conoidea, Watters, $\times 100,(3-5)$ Globorotalia (Globorotalia) plesiotumida (Blow and Banner), $\times 90$. 6-7. Globorotalia (Globoconella) inflata (d'Orbigny), Sample 606-2,CC, $\times 75$; note four-chambered form. 8-11. Sample 606-12-3, 120-122 cm, (8-9) Globorotalia (Globoconella) puncticulata (Deshayes), $\times 100$, (10-11) Globorotalia (Truncarotalia) crassaformis (Galloway and Wissler), $(10, \times 90 ; 11, \times 120) .12-15$. Globorotalia (Truncorotalia) cf. crassula (Hornibrook), Sample 606-13,CC, $\times 80$, (14-15) heavily encrusted forms. 